\title{
The Fate of Foodborne Pathogens in Manure Treated Soil
}

\author{
Zoe Black ${ }^{1,2,3}$, Igori Balta 2,4 , Lisa Black1, Patrick J. Naughton ${ }^{3}$, James S. G. Dooley³ and \\ Nicolae Corcionivoschi2,4* \\ ${ }^{1}$ Grassland and Plant Sciences Branch, AFBI Crossnacreevy, Sustainable Agri-Food Sciences Division, Agri-Food and \\ Biosciences Institute, Belfast, United Kingdom, ${ }^{2}$ Bacteriology Branch, Veterinary Sciences Division, Agri-Food \\ and Biosciences Institute, Belfast, United Kingdom, ${ }^{3}$ Nutrition Innovation Centre for Food and Health (NICHE), School \\ of Biomedical Sciences, Ulster University, Coleraine, United Kingdom, ${ }^{4}$ Faculty of Bioengineering of Animal Resources, \\ Banat University of Animal Sciences and Veterinary Medicine, King Michael I of Romania, Timisoara, Romania
}

The aim of this review was to provide an update on the complex relationship between manure application, altered pathogen levels and antibiotic resistance. This is necessary to protect health and improve the sustainability of this major farming practice in agricultural systems based on high levels of manure production. It is important to consider soil health in relation to environment and land management practices in the context of the soil microflora and the introduction of pathogens on the health of the soil microbiome. Viable pathogens in manure spread on agricultural land may be distributed by leaching, surface run-off, water source contamination and contaminated crop removal. Thus it is important to understand how multiple pathogens can persist in manures and on soil at farm-scale and how crops produced under these conditions could be a potential transfer route for zoonotic pathogens. The management of pathogen load within livestock manure is a potential mechanism for the reduction and prevention of outbreaks infection with Escherichia coli, Listeria Salmonella, and Campylobacter. The ability of Campylobacter, E. coli, Listeria and Salmonella to combat environmental stress coupled with their survival on food crops and vegetables postharvest emphasizes the need for further study of these pathogens along with the emerging pathogen Providencia given its link to disease in the immunocompromised and its' high levels of antibiotic resistance. The management of pathogen load within livestock manure has been widely recognized as a potential mechanism for the reduction and prevention of outbreaks infection but any studies undertaken should be considered as region specific due to the variable nature of the factors influencing pathogen content and survival in manures and soil. Mediocre soils that require nutrients could be one template for research on manure inputs and their influence on soil health and on pathogen survival on grassland and in food crops.

Keywords: manure, bacterial pathogens, soil, agriculture, pathogen persistence, zoonotic pathogens 


\section{INTRODUCTION}

With the global population continuing to rise, there is an everincreasing pressure placed on soil to support the intensification of agriculture (Waggoner, 1995; Tilman et al., 2002; Tomley and Shirley, 2009; Blaiotta et al., 2016; Manyi-Loh et al., 2016; Struik and Kuyper, 2017; Chaudhari et al., 2021). Agricultural demands vary from primary food source crop production to production of fodder crops and direct grazing used in livestock production. This demand, combined with a migration toward monoculture crop production systems, results in increasing amounts of manure, essentially a waste product, produced by livestock (Aarons et al., 2009; Plourde et al., 2013; Attwood et al., 2019). However, manures are now considered as organic fertilizer which is an essential resource to aid the intensification of agricultural production (McLaughlin et al., 2011; Mazur and Mazur, 2015; Chaudhari et al., 2021). Manures are routinely applied to grassland and arable sites, with multiple studies indicating an array of benefits such as provision of essential nutrients (e.g., potassium, phosphorous, nitrogen) for plant growth, increased soil carbon content, greater carbon sequestration and neutralization of soil acidity (Boateng et al., 2006; Risse et al., 2006; Zhang and Fang, 2007; Wortmann and Shapiro, 2008; Loss et al., 2019; Ekman et al., 2021). A study by Anwar et al. (2005) highlighted the benefits of manure utilization in tandem with inorganic fertilizers as an approach to sustainably improve both soil productivity and quality. Increasing reliance on manure as a soil enhancer, coupled with the need to dispose of snowballing waste production, has raised many questions regarding the safe use of manures to achieve and maintain sustainable agriculture (Pratt, 1979; Adegoke et al., 2016; ManyiLoh et al., 2016). Sustainable agriculture is defined as agricultural practices which can "meet current and future societal needs, for ecosystem services, and for healthy lives" (Tilman et al., 2002) and relies on the safe use of manures from a soil, crop, environment and human consumption perspective. The idea of Planetary Health identifies a link between human health, biodiversity and ecosystems, where nutrients and organisms introduced to the soil microbiome interact with the associated ecosystems (Zhu et al., 2019). The interaction with the associated ecosystems is dependent on human activity as it could place soil at the center of antimicrobial resistance spread due to the presence of pollutants which can include antimicrobials and antimicrobial resistant pathogens. The spread of animal manure as a soil amendment (Zeng et al., 2017) intensifies the spread of antimicrobial resistance genes (ARGs) as they are prominent in the animal gut due to the overuse of antibiotics in farming or due to the intensive use of in-feed antibiotics (Zhao Q. et al., 2018). This evidence clearly requires an understanding of the role of soil aligned with the use of manure to understand the dissemination of ARGs and pathogens within the environment.

Agriculture in Northern Ireland (NI) has changed considerably in the past 80 years with expanding livestock sectors, such as cattle and sheep production, resulting in a shift toward a predominantly grassland agriculture. Approximately 93\% of the total area farmed in NI is grassland (EARA, 2020).
Livestock farming is dominant in NI having doubled between 1940 and 2016 (EARA, 2020). Northern Ireland produces approximately 13 and $25 \%$, respectively, of the total manure output and total slurry output across the United Kingdom (UK) (Smith and Williams, 2016). This contribution of undiluted slurry production is high as the relative total land area of NI is approximately $5 \%$ that of the rest of the United Kingdom. The high ratio of slurry produced to area farmed, in tandem with slurry restrictions such as application limits of $30-50 \mathrm{~m}^{3}$ per hectare in one application, results in the need to control and balance the spreading of slurry on land as there is potential for excessive applications and misuse. In addition to cattle slurry, the NI livestock sector produces pig and poultry manures and additional manures in the form of digestates are produced from an increasing number of anaerobic digesters, which are often fed pig, poultry, and cattle waste (EARA, 2020). The Sustainable Agricultural Land and Management Strategy (SALMS) report (EARA, 2020) advises that the performance of NI soils is, mediocre with only $18 \%$ of analyzed soils at optimum fertility and only $36 \%$ of soils were reported as optimal $\mathrm{pH}$ for grass production. These low statistics for optimum soil health from a sector of high economic importance suggests NI soil systems could be a good template for research with regards to the influence of agricultural practices on soil health, particularly on grassland farming in a temperate setting. The heavy reliance on the livestock industry, increasing shifts toward intensive production systems (e.g., zero grazing systems) along with large livestock/area farmed ratios makes NI a key example of the potential influence of spreading of manure onto agricultural land. There is a possibility of designing and implementing changes with the aim of improving these statistics as soil health relationships are context-dependant (Yang et al., 2020).

The aim of this review was to provide an update on the complex relationship between manure application and altered pathogen levels. This is necessary to protect health and improve the sustainability of this major farming practice in the context of Northern Ireland, a useful model system for agricultural systems based high levels of manure production.

Soil health has been recognized as the ability of the soil to cope with anthropogenic factors associated with agricultural production, whilst maintaining the provision of ecosystem services (Kibblewhite et al., 2008; Larney et al., 2016). According to Kibblewhite et al. (2008), soil health is reliant on nutrient cycling, soil structure, transmission of carbon and pest/disease regulation (Kibblewhite et al., 2008). It is important to consider soil health in relation to environmental and land management practices. As soil fertility encompasses chemical, physical and biological properties, it can be considered a measure of soil health (Kibblewhite et al., 2008). Agricultural practices impact soil health in various ways (Bore et al., 2017; see Table 1). As common agricultural practices have the ability to influence these values, it is important to consider their role in achieving optimum production capacity from farmland. The application of fertilizers can have an indirect influence on soil bacterial communities by first altering the $\mathrm{pH}$ (Zhang et al., 2017). Changes in $\mathrm{pH}$ have been shown to alter the structure of the bacterial community present, and therefore have the potential to reduce soil health through 
TABLE 1 | Examples of the impact of common agricultural practices on soil health.

\begin{tabular}{|c|c|c|}
\hline Common practices & Example of impact on soil health / fertility & References \\
\hline \multirow[t]{5}{*}{$\begin{array}{l}\text { Monoculture cropping Over } \\
\text { grazing Tillage }\end{array}$} & Reduced and/or altered biological diversity & $\begin{array}{l}\text { Mikha and Rice, 2004; Zhao Y. et al., 2018; } \\
\text { Salaheen and Biswas, 2019; Yang et al., } 2020\end{array}$ \\
\hline & Reduced organic carbon content & \\
\hline & Soil nutrient depletion & \\
\hline & Decreased pH levels & \\
\hline & Soil structural change & \\
\hline \multirow{4}{*}{$\begin{array}{l}\text { Addition of artificial fertilizer } \\
\text { Addition of manure }\end{array}$} & Altered nutrient availability & Mikha and Rice, 2004; Bünemann et al., 2006 \\
\hline & Altered pH levels (e.g., soil acidification by added N) & \\
\hline & Altered biological diversity & \\
\hline & Soil structural change & \\
\hline
\end{tabular}

knock on effects of reduction of soil services such as nutrient cycling (Zhang et al., 2017).

To date, very little work has been carried out on the persistence of multiple pathogens in manures and on soil at farm-scale and the impact of both long and short term use of these manures on the soil microbial dynamics is not well understood (Wimalarathna et al., 2013; Li et al., 2017). Crops produced under these conditions have the potential to contain organisms found within the soil microbiome, therefore creating a potential route of transfer of pathogens into the food chain causing illness (Tilman et al., 2002; Larramendy and Soloneski, 2016; García-Sánchez et al., 2018). Some of the major zoonotic bacterial pathogens found in soil and manures are considered herein (Table 2).

\section{BACTERIA, MANURE, AND SOIL}

Bacteria can survive in varying oxygen concentrations, temperatures, $\mathrm{pH}$ levels and moisture contents. Significant correlations between bacterial diversity and annual precipitation and $\mathrm{pH}$ levels were found in a study of maize cropping systems in China (Tan et al., 2020). If microorganisms are incapable of coping with changing soil conditions they face competition and removal in the contest for nutrients (Ratzke and Gore, 2018). The newly arrived microorganisms find the new conditions favorable and will survive better than the native communities (Sharma and Reynnells, 2016). Predatory activity by organisms such as protozoans can also influence bacterial survival which is an important regulator of population levels (England et al., 1993).

The microbial populations associated with manure varies due to numerous influential factors, including the producing animal, its feeding regime and the waste management practices (Albihn and Vinnerås, 2007; van Vliet et al., 2007; Jokinen et al., 2012; Lopatto et al., 2019). Manure application can inadvertently spread zoonotic diseases to humans while both animal and plant populations can also be vulnerable to disease (Albihn and Vinnerås, 2007; Spiehs and Goyal, 2007; Longhurst et al., 2019; Tran et al., 2020). In addition to health implications for humans, livestock and crops, bacterial pathogens can also be costly to the economy. Effects encompass the direct costs and food sales effected by microbiological quality and production quantity concerns stemming from poor soil health and outbreaks of illness caused by bacterial pathogens (Swanenburg et al., 2001; Chlebicz and Śliżewska, 2018). Bacteria found in manures, e.g., E. coli and Salmonella, have often been implicated either directly or indirectly to outbreaks of human illness (Pell, 1997; Bicudo and Goyal, 2003; Guan and Holley, 2003; Hutchison et al., 2004). Viable pathogens contained within manure spread on agricultural land may be distributed by leaching, surface run-off, water source contamination and contaminated crop removal (Fenlon et al., 2000; Albihn and Vinnerås, 2007; Semenov et al., 2009; dikovic-Kolic et al., 2014; Alegbeleye and Sant'Ana, 2020; Mügler et al., 2021). A relationship therefore exists between agricultural practices and subsequent pathogen transfer to multiple ecosystems. For example, transfer of E. coli was shown from untreated poultry manure to fresh produce (Atidégla et al., 2016). Protecting food and water supplies from animal fecal contamination is of high importance in an attempt to preserve human health, animal health and agricultural sustainability (Pell, 1997; Kudva et al., 1998; Olson, 2001). Altered products may have a detrimental impact on human and livestock populations, particularly when contamination reaches areas beyond the agricultural land itself (Tilman et al., 2001, 2002; Sharpley et al., 2013; Ekman et al., 2021). There is a relationship between the source of manures and the pathogen content of the manure (Larramendy and Soloneski, 2016). Prevention of zoonosis within livestock populations is essential in order ensure high biosecurity standards (Albihn and Vinnerås, 2007; Layton et al., 2017) and the reduction of pathogen presence in manures will increase their sustainability and safe use in the environment (Barbour et al., 2002; Albihn and Vinnerås, 2007; Jung et al., 2014). Any studies undertaken should be considered as region specific due to the variable nature of the factors influencing pathogen content and survival in manures and soils (e.g., feed regime, climate, soil, and precipitation) (Bradford et al., 2013).

Soil is influenced by manure, with application reported to have positive impacts on the physical and chemical properties associated with soil health and fertility such as increased soil carbon content, water retention and nutrient supplies (Barbour et al., 2002; Wilson et al., 2008; Bradford et al., 2013; Jung et al., 2014). Large applications have the capacity to increase dispersion of soil particles by introducing high saline ion contents (Barbour et al., 2002). The apparent differences in the effect of manure application on soil structure and composition has been 
TABLE 2 | Background information for examples of zoonotic pathogens which occur in manure (CFU, Colony Forming Units; VNBC, Viable but non-culturable; STEC, Shiga toxin-producing Escherichia coli).

\begin{tabular}{|c|c|c|c|c|c|c|}
\hline Pathogen & Characteristics & Infective dose CFU & $\begin{array}{l}\text { Common agricultural } \\
\text { settings }\end{array}$ & $\begin{array}{l}\text { Common pathogenic } \\
\text { species }\end{array}$ & $\begin{array}{l}\text { Examples of survival } \\
\text { responses to } \\
\text { environmental } \\
\text { stresses }\end{array}$ & References \\
\hline $\begin{array}{l}\text { Campylobacter } \\
\text { spp. }\end{array}$ & $\begin{array}{l}\text { Helical microaerophilic, } \\
\text { Gram-negative }\end{array}$ & $500-800$ & $\begin{array}{l}\text { Poultry, cattle, pigs, } \\
\text { waterbodies }\end{array}$ & C. jejuni & $\begin{array}{l}\text { Biofilm formation VBNC } \\
\text { bacterial co-habitation } \\
\text { Attachment to biotic } \\
\text { and abiotic surfaces } \\
\text { through biofilm } \\
\text { formation Drug } \\
\text { resistance Host } \\
\text { invasion }\end{array}$ & $\begin{array}{l}\text { Stanley and Jones, } \\
\text { 2003; Murphy et al., } \\
\text { 2006; Bronowski et al., } \\
\text { 2014; Chlebicz and } \\
\text { Śliżewska, 2018; } \\
\text { Sibanda et al., } 2018\end{array}$ \\
\hline Escherichia coli & $\begin{array}{l}\text { Rod shaped, facultative } \\
\text { anaerobe, } \\
\text { Gram-negative. }\end{array}$ & $\begin{array}{l}\text { Extremely low e.g., } 10 \\
\text { CFU }\end{array}$ & $\begin{array}{l}\text { Cattle, pigs and sheep, } \\
\text { soil, water bodies }\end{array}$ & STECs e.g., O157 & & $\begin{array}{l}\text { Tuttle et al., 1999; } \\
\text { Fremaux et al., 2008; } \\
\text { Segura et al., 2018; } \\
\text { Capellini et al., 2020 }\end{array}$ \\
\hline Salmonella spp. & $\begin{array}{l}\text { Rod shaped, facultative } \\
\text { anaerobe, } \\
\text { Gram-negative. }\end{array}$ & $\begin{array}{l}\text { Debated, comparatively } \\
\text { higher than that of } \\
\text { Campylobacter and } \\
\text { E. coli }\end{array}$ & $\begin{array}{l}\text { Pigs, cattle, soil, water } \\
\text { bodies }\end{array}$ & Salmonella typhimurium & & $\begin{array}{l}\text { Waldner et al., 2012; } \\
\text { Dar et al., } 2017\end{array}$ \\
\hline Providencia spp. & $\begin{array}{l}\text { Rod shaped,facultative } \\
\text { anaerobe, } \\
\text { Gram-negative. }\end{array}$ & Suggested to be high & $\begin{array}{l}\text { Soil, water, livestock } \\
\text { intestines }\end{array}$ & Providencia stuartii & $\begin{array}{l}\text { Multi-drug resistance } \\
\text { Biofilm formation }\end{array}$ & $\begin{array}{l}\text { O'Hara et al., 2000; } \\
\text { Wie, 2015; El Khatib } \\
\text { et al., 2017; } \\
\text { Kurmasheva et al., } \\
2018\end{array}$ \\
\hline
\end{tabular}


attributed to varying climatic conditions. Greater soil leaching removed excess sodium ions from the soil, eliminating the negative impact seen in semi humid and arid soils (Wagenaar et al., 2013). Any changes to soil properties can lead to alterations of biological properties with potential to restructure the soil microbiome. Microorganisms included in manure are introduced to the soil during application (Murphy et al., 2006; van Vliet et al., 2007; Costa and Iraola, 2019). The introduction of foreign microbe populations, and changing environmental conditions (such as $\mathrm{pH}$ and salinity) may favor different microbes to the resident population and have the potential to influence the biodiversity and overall structure of the soil microbiome (Wallis, 1994; Kothary and Babu, 2001; Albihn and Vinnerås, 2007; Epps et al., 2013). For example, long term artificial fertilizers containing $\mathrm{N}, \mathrm{K}$ and $\mathrm{P}$ have been shown to reduce soil $\mathrm{pH}$ while composted cattle manures have been shown to increase $\mathrm{pH}$, crop yield and microbial activity in a flooded rice cropping system (Bronowski et al., 2014). Manure treated soils were found to have enhanced microbial activity with dominant bacteria such as Proteobacteria preferring high nutrient environments resulting from the breakdown of complex compounds. Soil which received no manure had dominant bacteria such as Acidobacteria, commonly found in nutrient limited soils (Stanley and Jones, 2003). However, Fernandez et al. (2020) found little direct influence of management practices on soil bacteria community structure, attributing variations in diversity to site locations instead (Szott and Friese, 2021). Increased crop yields could be linked to conditions, such as increased $\mathrm{pH}$, providing optimum conditions for bacteria associated with the provision of available nutrients for crop growth, in turn enhancing plant growth.

\section{BACTERIAL PATHOGENS IN MANURE}

Pathogen prevalence within different manures is subject to variables including producing animal species, feeding regimes and antimicrobial additives. Feeding regimes such as increased feed acidity has been proven to reduce Salmonella in fattening pigs (Bui et al., 2011). Manure application to soil may assist integration of pathogens with other environments through general pathways such as direct contact with livestock, contact with fresh produce and water bodies (dikovic-Kolic et al., 2014; Attwood et al., 2019; Rukambile et al., 2019). Pathogens react differently to stress and non-optimum conditions e.g., Listeria spp., are highly adaptable in low water availability, low $\mathrm{pH}$ and low temperature soil environments (Morita et al., 2004). Application of poultry and pig manure to arable lands has the potential to disseminate E. coli to soil and beyond (Murphy et al., 2006) and Salmonella have been identified in environments with little or no oxygen, e.g., slurry pits, and at low temperatures (Colles et al., 2008). The repetitive nature of modern farming, monoculture crops and similar livestock populations (i.e., hosts) in particular areas, allow pathogens to adapt and specialize in the survival and reinfection of existing host populations (Wesley et al., 2000). The impact of monoculture on bacterial diversity in soils is dependent on crop rotations (An et al., 2018). Pathogens are less likely to thrive in genetically diverse ecosystems which supports the theory that repetitive farming may cause pathogen populations to become established within the farming environment (Harvey et al., 1999).

Bacterial pathogens found within manure and associated with bacterial outbreaks include, but are not limited to, Campylobacter, Salmonella and strains of pathogenic E. coli such as O157:H7 (Swanenburg et al., 2001; Indikova et al., 2015; Manyi-Loh et al., 2016; Zhong et al., 2020). An example of an emerging pathogen found in manure and soil is Providencia spp. and it is an important reminder of the need for ongoing surveillance in an area that is likely to experience change as agricultural practices evolve. Campylobacter spp.

\section{Campylobacter spp.}

Campylobacter is one of the most common causes of food-borne diseases in the United States of America and Europe (Murphy et al., 2006; Wilson et al., 2008; Wagenaar et al., 2013; Costa and Iraola, 2019). Humans can develop campylobacteriosis from a low infective dose of only 500-800 CFU (Wallis, 1994; Kothary and Babu, 2001; Epps et al., 2013). and Campylobacter jejuni is responsible for most cases of infection (Epps et al., 2013; Costa and Iraola, 2019). Campylobacter spp. have been reported in unpasteurized dairy products, untreated water and manures (Stanley and Jones, 2003; Wagenaar et al., 2013; Bronowski et al., 2014; Szott and Friese, 2021) and are prevalent in many food-producing animals including poultry, cattle, sheep and pigs (Szott and Friese, 2021). It has been reported that $100 \%$ of Campylobacter isolates from poultry and cattle fecal samples are C. jejuni while $97 \%$ of pig fecal isolates were identified as C. coli (Morita et al., 2004; Colles et al., 2008; Bui et al., 2011; Rukambile et al., 2019). Other studies have shown that cattle are common reservoirs of C. jejuni and C. lari (Wesley et al., 2000; An et al., 2018). Harvey et al. (1999) highlights the prevalence of C. jejuni in pigs, albeit a lower rate than C. lari. Morita et al. (2004) determined prevalence of Campylobacter spp. in cattle, and pig and poultry fecal samples of 76.0, 63.8, and $50.0 \%$, respectively which could potentially represent a source of contaimination in soils via manure application as C. jejuni can adapt to non-ideal environments tolerating higher oxygen levels and reduced nutrient availability (Bronowski et al., 2014). It has been suggested that Campylobacter can increase biological diversity, by lowering of oxygen concentrations thereby reducing oxygen stress with $C$. jejuni having been shown to contribute to mixed culture biofilm under aerobic conditions (Zhong et al., 2020). Increased survival success has been demonstrated in cultures containing Pseudomonadaceae as Campylobacter possess the ability of to attach to their biofilms (Indikova et al., 2015). Their ability to enter the viable but non-culturable state (VBNC) in response to high oxygen levels has been recognized, however, the infectiveness of the VBNC is not well documented (Bronowski et al., 2014; Zhong et al., 2020; Szott and Friese, 2021). Temperature has been suggested as a key factor in the ability of Campylobacter to survive in the environment. An investigation by Bui et al. (2011) determined that C. coli was more sensitive to aerobic conditions at temperatures of $15^{\circ} \mathrm{C}$ or more compared to temperatures of $4^{\circ} \mathrm{C}$, suggesting temperature is a key factor in the response to stresses such 
as oxygen content (Bui et al., 2011). A study by Brandl et al. (2004) demonstrated better C. jejuni survival on plant roots and leaves at lower temperatures $\left(10\right.$ and $\left.16^{\circ} \mathrm{C}\right)$, than at higher temperatures $\left(33\right.$ and $37^{\circ} \mathrm{C}$ ). The same study identified a relative increase in survival of C. jejuni on wounded plant leaves at $10^{\circ} \mathrm{C}$, suggesting potential for amplified survival during harvest and food preparation. It has been suggested that the frequency of campylobacteriosis is due to the prevalence of the organism in different environments, such as meat plants, once shed from animal hosts (Li et al., 2017). Campylobacter are thought not to multiply outside of a host due to environmental stresses and lack of survival at oxygen concentrations above 5\% (Brandl et al., 2004; Wimalarathna et al., 2013; Li et al., 2017; García-Sánchez et al., 2018; Gundogdu and Wren, 2020).

\section{Escherichia coli}

The facultative anaerobe $E$. coli is diverse with a wide range of pathotypes (such as O157) that have an assortment of impacts on humans which range from harmless to lethal (Maule, 1997; Winfield and Groisman, 2003; Yan and Polk, 2004; Delmas et al., 2015). Specific pathogenic strains cause gastrointestinal disease in humans (Kaper et al., 2004), including Shiga-toxin producing E. coli (STEC)-e.g., E. coli O157 (Williams et al., 2005; Pennington, 2010). Food-producing animals are sources of pathogenic E. coli and may be symptomatic or asymptomatic and, while the infective dose is currently being debated, the general consensus is that a low dose will cause infection (Kirk, 1998; Tuttle et al., 1999; Schmid-Hempel and Frank, 2007). Oporto et al. (2008) determined that $50.8 \%$ and $35.9 \%$ of sheep and cattle herds, respectively, were carriers of shiga toxin producing strains of pathogenic E. coli (Oporto et al., 2008).

Pathogenic E. coli, and STEC strains in particular, is a hardy bacterium which can survive for extended periods in water, soil and manure (Maule, 1997; Kirk, 1998; Olson, 2001; Williams et al., 2005; Wiles et al., 2008; Chekabab et al., 2013; Iwu et al., 2021). E. coli $\mathrm{O} 157$ is sensitive to dehydration/desiccation (Jiang et al., 2002; Williams et al., 2005; Vidovic et al., 2007). E. coli persistence was shown at $59.1 \%$ of chicken litter samples taken from urban poultry farms in Cameroon (Ngogang et al., 2021). Xing et al. (2019) showed that diverse microbial populations reduced the invasive capacity of E. coli (van Elsas et al., 2012). In non-autoclaved soils, survival was higher at $5^{\circ} \mathrm{C}$ than $15^{\circ} \mathrm{C}$ which may be attributed to the ability of $E$. coli to adapt and survive at lower temperatures and could play a part in survival within soil (Jiang et al., 2002). A study by Yao et al. (2015) focused on E. coli $\mathrm{O} 157$ survival in microbial active soils in southeast China. They reported a reduction from $10^{6} \mathrm{CFU} \mathrm{g}^{-1}$ to $100 \mathrm{CFU} \mathrm{g^{-1 }}$ at a temperature of $25^{\circ} \mathrm{C}$ in chicken manure amendments after $2.57 \pm 6.57$ days. Pig manure amendments required $25.65 \pm 7.12$ days for a similar level of reduction. E. coli O157 survival in soil has been shown to increase in soils of higher $\mathrm{pH}$ and lower diversity. Studies linking the influence of environmental factors such as soil $\mathrm{pH}$ and microbial diversity to $E$. coli survival in soil, in tandem with the influence anthropogenic factors such as manure amendments, could allow for greater transmission across the environment (Jiang et al., 2002; van Elsas et al., 2012; Yao et al., 2015). The high prevalence of E. coli in soils highlights the need for proper management of manure resources, particularly prior to spread on agricultural soils (Sobur et al., 2019).

\section{Salmonella spp.}

Salmonella is a facultative anaerobe with many serotypes capable of causing gastroenteritis in humans. Some serotypes of Salmonella can cause infection and fatalities in livestock (e.g., some Salmonella Typhimurium and Salmonella Choleraesuis strains in pigs) but can also exist as a subclinical infection where no symptoms are detected (Smith et al., 2018). The infective dose is debated throughout the literature, but most agree that the dose required is comparatively higher than for that of Campylobacter and E. coli (Blaser and Newman, 1982; Kothary and Babu, 2001; Vernozy-Rozand et al., 2002; Hara-Kudo and Takatori, 2011). An increase in the occurrences of antimicrobial resistant strains of Salmonella has been reported (Monack, 2012; Williamson et al., 2018), where $S$. Typhimurium has been the most frequently encountered (Glenn et al., 2011).

Salmonella survival in soil is dependent on variables such as temperature, predation and introduction method (Jacobsen and Bech, 2012). Guo et al. (2002) reported Salmonella transmission to tomatoes from inoculated soils (Guo et al., 2002). Tomatoes placed with cut stem facing topsoil, saturated with sterile water saw population increases of $2.5 \log _{10} \mathrm{CFU}$ over an initial 4-day period following inoculation and this remained constant up to 10 days at a storage temperature of $20^{\circ} \mathrm{C}$ and high humidity. The same study determined that Salmonella levels remained constant within the soil over an initial 14-day period with only a small decline over a 45-day period. This suggests that in certain conditions, fruits such as tomatoes exposed to Salmonella contaminated soils may be enablers of bacterial population growth/maintenance, as well as a vehicle for transmission to human populations. Elimination of such bacteria prior to manure spreading could greatly reduce this risk. Salmonella spp. were observed to invade the flesh of tomatoes (Guo et al., 2002), lettuce and whole green onion (Ge et al., 2012) a process referred to as Salmonella internalization-which suggests that typical washing techniques may fail to remove the bacteria and reduce the risk of infection. Ge et al. (2012) determined that weather events have the potential to aid internalization. This highlights the need for area specific studies and legislation as climate and weather events are variable depending on location (Ge et al., 2012). Salmonella spp. are reported to survive for prolonged periods outside of a host should environmental conditions be favorable-for example, moisture, temperature, predation and soil type as reviewed by Jacobsen and Bech (2012). Semenov et al. (2009) reported longer survival times of S. typhimurium in surface applied manure (estimated 60 days) compared to $10 \mathrm{~cm}$ injected slurry (estimated 28.6 days) showing a clear influence of the application method (i.e., surface spreading or injection) and type of material applied (i.e., manure or slurry) (Semenov et al., 2009). Survival of Salmonella within the soil is also influenced by the ability to respond rapidly to stress such as entering harsh, non-optimal environments such as soil (Waldner et al., 2012). Spector and Kenyon (2012) explain that by entering the VNCS quickly, the organism allows for survival in a dormant state in under conditions that could 
otherwise be lethal (Spector and Kenyon, 2012). In both soil and manure-amended soil S. typhimurium has been shown to persist longer at lower temperatures. It has been suggested that notably reduced survival rates of $S$. Typhimurium in manure-amended soils at any temperature is related to protozoan predation (Garcia et al., 2010).

\section{Providencia spp.}

Providencia spp. are Gram negative, rod shaped, and facultative anaerobic bacteria which are part of the family Enterobacteriaceae (Beattie et al., 2020; Esperón et al., 2020; Massé et al., 2021). The well-studied species include $P$. stuartii, $P$. alcalifaciens, and, $P$. rettgeri with these bacteria linked to gastroenteritis, Urinary Tract Infections (UTIs) and bacteraemia (Holman et al., 2016; Chuppava et al., 2019; Esperón et al., 2020; Yoshizawa et al., 2020; Congilosi and Aga, 2021). Providencia spp. are considered opportunistic (Massé et al., 2021) and often have the greatest impact on those with weakened immune systems such as the elderly, young children and patients whose immune system was compromised by surgery or burns (Blaiotta et al., 2016; Checcucci et al., 2020; Miller et al., 2020). Infections caused by this genus are less common than other bacterial pathogens such as Salmonella and E. coli, however, they are associated with high mortality rates, particularly in instances where infection of a urinary catheter occurs (Esperón et al., 2020). P. rettgeri and $P$. stuartii are frequently found in soil, water and animal hosts (Agga et al., 2020; Esperón et al., 2020). A study by Resende et al. (2014) identified the presence of Providencia spp. albeit at low incidence in the investigation of cattle manure following anaerobic digestion (Laconi et al., 2021). Isolation of this bacteria is often unintentional where presumptive positives for other bacteria are determined to be Providencia spp. e.g., a report by Blaiotta et al. (2016) found many isolates obtained from cattle manure were in fact Providencia spp. as identified by $16 \mathrm{~S}$ rDNA sequencing and not presumptive species such as Shigella (Blaiotta et al., 2016). Information as to their infection of farm animals is limited, however, the genus has been cited as exhibiting high levels of antimicrobial resistance (AMR) (Esperón et al., 2020) and while infection by Providencia spp. is rare, there are potential reservoirs of ARGs in the wider environment (Beattie et al., 2020). It would be beneficial for future studies to investigate the prevalence the impact of Providencia spp. within manure and soil microbiomes.

\section{Listeria spp.}

Listeria monocytogenes was isolated from the soil samples in multiple studies indicating the ubiquity of the pathogen in the natural environment and it was detected as being involved in a series of agricultural and food product-associated outbreaks (Falardeau et al., 2018). Its presence in soils is probably related to its increased resistance harsh temperatures and oxidative stress, increased saline concentrations, acid and desiccation stress (Iwu and Okoh, 2020). Soils characteristics such as a high content of molybdenum were reported to carry higher concentrations of L. monocytogenes (Liao et al., 2021) suggesting that such conditions can lead to increased surviability. This bacterium can survive for up to 84 days in soils but higher survival rates for up to 295 days were also detected (Welshimer, 1960; Locatelli et al., 2013). Its persistence in soil depends on intrinsic factors such as physiological state, abiotic factors (physical and chemical conditions), precipitation and temperature, and its also highly depenedent on biotic environmental factors such as inhibitory molecules, protozoan grazing and competition for substrate (Vivant et al., 2017).

Understanding of how Listeria adapts to different environmental settings is very important, and the adaptation to the new types of matrices necessitates a genetic adaptation (Vivant et al., 2017). In farm environments the causative agent of listeriosis, $L$ monocytogenes, was reported to express high resilience to different waste treatments, plus was still present for more than a month in amended soils even without livestock effluents (Hutchison et al., 2005; Moynihan et al., 2015). It has been shown that the bacterium's adaptability to soil environments can be reduced through the impairment of AgrA gene expression, which regulates motility, chemotaxis, transport and metabolism of amino acids (Marinho et al., 2020). Specifically, AgrA and $\sigma \mathrm{B}$ factors control the general stress response and can cooperatively modulate the L. monocytogenes transcriptome to induce a more precise adaptation and an optimal growth and survival rate. Another similar example of genetic adaptation in a soil environment is represented by the two-component systems recently identified as LisRK (Brunhede et al., 2020). This system controls tolerance to several stresses and is important for pathogen growth and survival in sterile and non-sterile soils (Brunhede et al., 2020).

The high virulence potential of Listeria, specifically of the strain monocytogenes, is attributed to several molecular factors which are associated with multiple phases of the infection. At the onset of infection, genes such as inlA, inlB, inlF, and inlJ are responsible for adhesion and invasion and are followed by the expression of $h l y, m p l, p r f \mathrm{~A}, \operatorname{act} \mathrm{A}$, and $p l c \mathrm{~B}$ genes which are responsible for the growth and spread of the bacterium (Iwu and Okoh, 2020). According to recent findings, such genes are present in isolates collected from irrigation waters and agricultural soils alongside multiple antibiotic-resistant factors such as aadA, tet $\mathrm{A}$, tetB, tetC, sulI, sulII, and aac(3)-IIa genes (Iwu and Okoh, 2020).

\section{PREVALENCE}

The management of pathogen load within livestock manure has been widely recognized as a potential mechanism for the reduction and prevention of outbreaks infection with E. coli, Salmonella and Campylobacter (Wang et al., 1996; VernozyRozand et al., 2002; Lim et al., 2010; Larramendy and Soloneski, 2016). The importance of good hygiene practices so the manures are safe for use, i.e., allowing for optimum production that does not compromise environmental health has been outlined (Alegbeleye and Sant'Ana, 2020). Manure handling methods vary greatly across agricultural setups depending on the type of livestock housing, amount of manure produced etc. For example, manure produced in NI is handled mainly as slurry (Smith and Williams, 2016) and many studies have identified different management techniques as factors in pathogen load reduction 
(Table 3). Nicholson et al. (2005) reported 3-month maximum survival times in stored slurries which frequent temperatures over $20^{\circ} \mathrm{C}$ for E. coli $\mathrm{O} 157$ and Salmonella. These bacteria survived up to 32 days in $7 \%$ dry matter dairy slurry, and up to 93 days $2 \%$ dry matter dairy manure suggesting that manure with a greater dry matter content reduces pathogen populations at a greater rate with reference to temperatures, moisture content and $\mathrm{pH}$. Data from Nicholson et al. (2005) reported lower maximum survival times of 1 month or less for the same inoculated pathogens in manure composting heaps which commonly reached temperatures above $55^{\circ} \mathrm{C}$, suggesting that handling of manure as a solid is a feasible method of pathogen reduction due to higher temperatures being reached. In contrast, a review by Guan and Holley (2003) highlighted potential benefit in treating manures as a liquid where possible, as less time is required to kill pathogens at 25 and $37^{\circ} \mathrm{C}$ as temperatures are easier to maintain in the liquid state (Guan and Holley, 2003). Storage of manure at $25^{\circ} \mathrm{C}$ would reduce pathogen loading (e.g., E. coli O157, Salmonella, and Campylobacter) below detectable levels after a period of 90 days. In this context it is difficult to compare data as many variables can influence the survival of pathogens within the manures. For example, Wang et al. (1996) determined that larger populations of inoculated enterohemorrhagic E. coli survived longer at both 37 and $22^{\circ} \mathrm{C}$, which would infer that in inoculation experiments, larger populations may react and survive differently to smaller levels of initial inoculum used (Wang et al., 1996). This report noted a more rapid decline in population at $37^{\circ} \mathrm{C}$ which is potentially linked to the desiccation at these prolonged temperature exposures, hence the warmer temperature of $37^{\circ} \mathrm{C}$ showed higher reduction in population numbers. E. coli were seen to survive for up to 8 weeks in the feces at $37^{\circ} \mathrm{C}$, where it was possible the survival was sustained by non-uniform dehydration across the feces. Maule (1997) showed a depletion of viable E. coli O157 populations in cattle manure from levels of $10^{8} \mathrm{CFU} \mathrm{g}^{-1}$ to less than $100 \mathrm{CFU} \mathrm{g}{ }^{-1}$ after 9 days at $18^{\circ} \mathrm{C}$ (Maule, 1997). Kudva et al. (1998) reported better survival of E. coli O157 in naturally occurring populations within manure than in artificially inoculated populations within laboratory experiments (Kudva et al., 1998). The same report showed depletion of viable numbers of E. coli $\mathrm{O} 157$ in cattle slurry to undetectable levels within 5 days at temperatures of 23 and $37^{\circ} \mathrm{C}$, whilst a temperature of $4^{\circ} \mathrm{C}$ saw detectable levels of $10^{5} \mathrm{CFU} \mathrm{g}^{-1}$ after 28 days. For most relatable impact, as pathogen survival is highly variable within laboratory and field experiments, studies would benefit from a focus on field experiments with reference to the ultimate location of the manure application rather than to slurry microcosms in the laboratory.

\section{MANURE AS A VECTOR OF ANTIMICROBIAL RESISTANCE}

The carriage of resistant and pathogenic bacteria, ultimately facilitating the spread of antimicrobial resistance in the environment via animal manure as fertilizers, poses a latent risk for transferring ARGs from animals and animal products to the human microbiome (Zhang et al., 2019). An example of ARG transmission to humans occurred via gene transfer from manured soil to vegetables and was previously observed in lettuce, which underlines the possible risks of transition of plant modified resistome to the human food chain (Zhang et al., 2019). Another illustration of ARG transmission in the food chain was recently identified in fresh vegetables and fruits from southern China, where Tet and ami genes were present at a very high frequency displaying an average abundance of 3.08 and 1.18 copies per 16S rRNA gene copies (Xiong et al., 2019). In addition, the presence of aadA, aph1, floR, sul1, intI1, qacE, sul2, tetB, and tet $M$ from the food samples displayed the detection frequency above $90 \%$, while $\mathrm{cmlA}$ and ermB depicted slightly lower values.

Several classes of antibiotics are used in food-farm production of which the main are considered tetracyclines which encodes tet genes family, sulfonamides encompassed from three types of sul genes, $\beta$-lactams are represented by $b l_{T E M}$ and $b l a_{C T X}-M$ genes, macrolides that carry erm and mef genes, colistins with different $\mathrm{mor}$ genes and quinolones which encodes a family resistant qnr genes (Lima et al., 2020). The genes presented in association with animal manure can also attribute resistance to disinfectants in addition to aminoglycosides, tetracyclines, sulfonamides and macrolide-lincosamide-streptogramin B (MLSBs). Resistance genes are frequently linked on mobile genetic elements (MGEs) such as specific plasmids, transposons and insertion sequences/gene cassettes. The latter can capture genetic material from various environmental sites and distribute them amongst the other bacterial species via horizontal gene transfer (Muurinen et al., 2017).

It has been suggested that the analysis of the animal manure and soil resistomes can play a fundamentally important role to underline necessary antimicrobial resistance mechanisms and evaluate the public health risks that might be caused by livestock effluents (Noyes et al., 2016). Moreover, manuresoil microcosms may be reproduced to investigate the spread process of ARGs from animal manure to humans and suggest mechanisms to limit the expansion of ARGs (Wang et al., 2017). First of all, ARG management could focus on eliminating ARGs bearing a low natural reduction potential (e.g., sull, sul2, intl1, and tet $M$ ) prior to the manure being applied to the soils. Changing some of the manure handling practices to the novel manure handling methods can potentially reduce the abundance of ARGs in manure utilized for land treatments (Ruuskanen et al., 2016; Gurmessa et al., 2021). Processes such as extending windrow composting and stockpiling have previously been shown to reduce resistance determinants of erythromycin, tetracycline and sulfamethazine between 0.5 and $3 \operatorname{logs}$ in contrast to original cattle manure levels (Xu et al., 2016).

The concentrations of ARGs from livestock waste are found in much higher proportions than the human waste and manured soil, with the reported levels of ARG approximately 28,000 times higher than in un-manured soil (Lima et al., 2020). Within a study, 109 ARGs related to the veterinary and human antibiotic practices were recently identified from fresh poultry, swine and cattle manure of 12 large production-scale Chinese farms (Lima et al., 2020). 
TABLE 3 | Studies of manure pathogen load survival in agricultural soil.

\begin{tabular}{|c|c|c|c|c|c|c|}
\hline Sample type & Study location & Detection method & Pathogen & Manure treatment & $\begin{array}{l}\text { Maximum survival } \\
\text { (days) }\end{array}$ & References \\
\hline $\begin{array}{l}\text { Inoculated dairy slurry } \\
\text { (7\% dry matter) }\end{array}$ & $\begin{array}{l}\text { Field study- } \\
\text { Nottinghamshire, } \\
\text { United Kingdom. }\end{array}$ & $\begin{array}{l}\text { Selective agar plating } \\
\text { following selective } \\
\text { enrichment culturing } \\
\text { method }\end{array}$ & $\begin{array}{l}\text { E. coli O157 Salmonella } \\
\text { spp. Campylobacter } \\
\text { spp. }\end{array}$ & On farm storage & 3218532 & Nicholson et al., 2005 \\
\hline $\begin{array}{l}\text { Inoculated dairy slurry } \\
\text { ( } 2 \% \text { dry matter) }\end{array}$ & & & $\begin{array}{l}\text { E. coli O157 Salmonella } \\
\text { spp. Listeria spp. } \\
\text { Campylobacter }\end{array}$ & & 939318532 & \\
\hline $\begin{array}{l}\text { Cattle manure added to } \\
\text { sterile soil }\end{array}$ & Laboratory, America. & $\begin{array}{l}\text { Direct plating method } \\
\text { of selective agar plaiting } \\
\text { of soil suspensions. }\end{array}$ & E. coli O157 & Incubation $21^{\circ} \mathrm{C} 5^{\circ} \mathrm{C}$ & 23177 & Jiang et al., 2002 \\
\hline $\begin{array}{l}\text { Chicken manure } \\
\text { applied to non-sterile } \\
\text { soils }\end{array}$ & Laboratory, China., & $\begin{array}{l}\text { Direct plating method } \\
\text { of selective agar plaiting } \\
\text { of soil suspensions. }\end{array}$ & E. coli O157 & Incubation $25^{\circ} \mathrm{C}$ & $\begin{array}{l}2.57 \pm 6.57 \text { (reduction } \\
\text { from } 10^{6} \text { to }<100 \mathrm{CFU} \\
\mathrm{g}^{-1} \text { ) }\end{array}$ & Yao et al., 2015 \\
\hline $\begin{array}{l}\text { Pig manure applied to } \\
\text { non-sterile soils }\end{array}$ & & & & & $\begin{array}{l}25.65 \pm 7.12 \\
\text { (reduction from } 10^{6} \\
\text { to }<100 \mathrm{CFU} \mathrm{g^{-1 }} \text { ) }\end{array}$ & \\
\hline Pig manure & Laboratory, Denmark. & $\begin{array}{l}\text { Direct plating method } \\
\text { of selective agar plaiting } \\
\text { of soil suspensions, } \\
\text { qPCR, RT-qPCR }\end{array}$ & Campylobacter coli & $\begin{array}{l}\text { Incubation } 4^{\circ} \mathrm{C} 15^{\circ} \mathrm{C} \\
22^{\circ} \mathrm{C}\end{array}$ & 2476 & Bui et al., 2011 \\
\hline Manure amended soils & - & & Salmonella spp. & - & Up to 332 & $\begin{array}{l}\text { Jacobsen and Bech, } \\
2012\end{array}$ \\
\hline
\end{tabular}


Fresh manure application was reported to induce more ARGs in the land than stockpiled manure, which introduces a lesser amount of ARGs (Xu et al., 2021). Previous studies found that the dissipation of ARGs via composting of manure enriched with antibiotics showed distinct differences in contrast to the manure produced by cattle with the dietary inclusion of antimicrobials (Xu et al., 2018). For example, the genes such as ermX, sul1, sul2, and tetB were detected in cattle manure after 175 days of post-excretion, which may pose a pollution risk factor of ARGs dissemination if such manure will be further applied into the field. The most prevalent and highly proportional gene set identified in the cattle manure is tetracycline resistance tet $M$ and tet $W$ genes. During the composting process, the intensity of erythromycin, sulfamethazine and tetracycline resistance gene can be reduced. However, others can remain stable, and prolonged thermophilic composting phases is suggested to decrease the dissemination of ARGs into the encircling environment upon field application of composted manure (Xu et al., 2018).

It is also very important to evaluate persistence studies of ARG from manure soil microcosms in order to understand the environmental antimicrobial resistance status and the shifts in resistance between bacterial communities. A recent study investigated two sets of simulated manure-soil microcosoms by sequencing $16 \mathrm{~S}$ rDNA to observe bacterial community diversity and directly measuring the fate of ARGs, including cfr, ermB, ermF, fexA, intI1, sul1, sul2, tetB, and tetM and revealed interesting differences in persistence (Wang et al., 2018). Following 90 experimental days, the abundance of ARG from poultry manure showed significant decreasing trends, while the diversity and richness of species in soil were notably increased. The decay rate of sul1, sul2, tetM, and intI1 within the soil was lower for this set of genes whilst ermB and ermF genes exhibited increased dissipation rates. Cattle manure contained a more prominent macrolide ermB and sull resistant gene set than the poultry litter (Gurmessa et al., 2021). The observation of the wide distribution of erm genes was linked with erm proteins accountable for the demethylation of singular adenine base from the $23 \mathrm{~S}$ rRNA, which is a region that encodes targets for lincosamides, macrolides and streptogramins $\mathrm{B}$ that explains the wide-spreading resistance potential of that gene. Indoors to this study, the expression of the $c f r$ abundance was weaker expressed (Wang et al., 2018). The cfr is generally associated with the plasmid presented in Staphylococcus isolates and is collectively expressed with erm resistance genes. Similarly, their study reported a decreased tet $B$ abundance which is usually connected with the presence of Gram-negative bacteria, compared with tet $M$ that is correlated with all types of bacteria. Recently a total of 67 multi-drug methicillin-resistant Staphylococcus sciuri were isolated from the 400 environmental samples, of which 40 specimens were from manure, while 360 were from the soil. Strikingly, a major proportion of S. sciuri isolates displayed a huge resistance with approximation above $90 \%$ against ampicillin, clindamycin, penicillin, cefoxitin and ceftiofur, as well as $86.56 \%$ resistance against tetracycline and $50.74 \%$ for erythromycin (Kumar et al., 2017). Finally, the study also identified major antibiotic-resistant genes such as ermA,
ermB, erm $C, \operatorname{mec} A, \operatorname{aac}\left(6^{\prime}\right), \mathrm{Ie}-\mathrm{aph}\left(2^{\prime \prime}\right) \mathrm{Ia}$, tet $M$, tet $K$, and $m p h C$ thereby highlighting the dissemination potential of such genes via spreading of swine manure.

In a recent trial that aimed to decrease the pathogen load, the residues of antibiotics and ARGs from poultry manure via composting technique at a field scale were determined and a 10-week intervention was shown to be sufficient to achieve optimized results (Esperón et al., 2020). Firstly, from the sixteen of ARGs, a larger proportion of them declined from the initiation till the end of the experiment by showing remarkable statistically reductions for tet genes $(A, B, K, M, Q$, $\mathrm{S}, \mathrm{W}), \mathrm{ermB}, \mathrm{qnrS}$, and bla $a_{T E M}$. After 3 weeks of composting, the antibiotic fraction of ciprofloxacin and doxycycline decreased by approximately $90 \%$ and reduced the presence of pathogens such as $C$. coli and E. coli. Furthermore, the addition of barley straw influenced the OTUs at the phylum level by causing increasing shifts as was noticed in the magnification of the Flavobacteria class, which after 1 month was surpassed by the class of Sphingobacteria and the composting application modified the bacterial community in favor of the leading order of Bacillales (Esperón et al., 2020).

E. coli isolated from manure and environmental samples are considerably different from the clinical isolates, which were reported to show resistance patterns against ampicillin, ceftazidime, ceftriaxone, ciprofloxacin, gentamicin, trimethoprim-sulfamethoxazole and levofloxacin (Beattie et al., 2020). Compared to more virulent clinical E. coli isolates, those isolated from manure and environmental samples also harbor the plasmids and the potential to develop biofilms responsible for producing a plethora of ARGs (Beattie et al., 2020). A Canadian study isolated E. coli from fecal samples from cows, calves and manure pits from dairy farms of Québec. These displayed increased resistance levels toward streptomycin, sulfisoxazole and tetracycline with the main responsible AMR genes aadA1, $\operatorname{aad} A 2$, aadA5, aph(3")-Ib (strA), aph(6)-Id (strB), tet $A, \operatorname{tet} B$, sul1, sul2 and sul3 (Massé et al., 2021). The analysis of extendedspectrum $\beta$-lactamase from $E$. coli samples showed two distinct phenotypes as $A m p C$ and ESBL that involved resistance genes $b l a_{C M Y-2}$ and $b l a_{C T X}-M$. The environmental dissemination of ESBL and $A m p C$ producing E. coli is considered a public health risk factor (Massé et al., 2021). In a German study, approximately $17 \%$ of $E$. coli isolates from poultry manure, and excreta exhibited resistance to four antibiotics: Enrofloxacin, Ampicillin, Tetracycline and Sulfamethoxazole-trimethoprim (Chuppava et al., 2019). Antibiotic-resistant patterns were probably attributed to the fattening practices that might be an outcome of intensive farming.

A similar parallel was observed in a recent study for the cattle manure where the fungal genus Kernia, along with Proteobacteria and Bacteroidetes, were enriched from day 0, while enrichment of the Firmicutes began at day 99 (Holman et al., 2016). The AMR genes were significantly diminished in concentration over time. The decreases of the 10 out of the 12 antimicrobial resistance determinants and a decline fungal richness by approximately 10 -folds compared with bacterial richness was associated with the composting operation by raising the temperature above $55^{\circ} \mathrm{C}$ (Holman et al., 2016). 
In a recent trial from Japan, spiked E. coli from manure compost was reduced below the detection limit after $55^{\circ} \mathrm{C}$ incubation within 1 day (Yoshizawa et al., 2020). The study concluded that proper composting could degrade the concentrations of antibiotic-resistant pathogens and ARGs, nevertheless, complete elimination is still difficult to achieve. For instance, physicochemical treatment such as activated carbon with microwave pre-treatment coupled with anaerobic digestion successfully removed several manure contaminants, including ARGs affiliated with macrolides, tetracyclines and sulfonamides (Congilosi and Aga, 2021).

The thermophilic composting process of the poultry, cattle and swine manure can reduce the ARG levels by up to 2.0 logs depending on the type of operational treatment and type of the manure (Checcucci et al., 2020). In another study, swine manure application under 120-day simulated winter incubation decreased the tetracycline resistance genes except for tet $M$ and tet $O$ genes that persisted in the soil (Miller et al., 2020). Another study concluded that mesophilic anaerobic digestion of the cattle, poultry and swine manure could reduce the proportion of tetracyclines but conversely increase tet and methicillin resistance genes and increase the amounts of total bacteria, E. coli, enterococci and S. aureus, therefore requiring the need for additional optimizing of the post-digestion operation (Agga et al., 2020). Some of the studies claimed that manurederived bacteria do not persist in soil for a long time, and manure treatment does not radically affect the soil's microbiome (Laconi et al., 2021). However, flumequine can likely exhibit selective pressure for oqxA and qnrS gene accumulation in fertilized soils.

A study based on the investigation of antibiotic-resistant pathogens from chicken litter manure sampled on site from 26 farms in Cameroon has recently detected multidrugresistant E. coli spp. and Salmonella spp. isolates (Ngogang et al., 2021). The authors reported that all of the tested E. coli isolates showed multi-drug resistant patterns, including one isolate resistant to 9 antibiotics out of 11 , and $28 \%$ of E. coli isolated cultures were at least resistant to five antibiotics (Ngogang et al., 2021). In parallel 36\% of the Salmonella spp. were multi-drug resistant and $27 \%$ of the isolates were susceptible to all 11 of the antibiotics. Studies conducted in US farms had earlier reported that Salmonella spp. with an increased MDR frequency (58.73\%) for at least three or more classes of antibiotics that were isolated from the pig manure application and consequently spread on the land were able to persist for a minimum of 21 days (Pornsukarom and Thakur, 2016). Lately, the same authors found that antimicrobial-resistance plasmids between Salmonella serotypes were able to persevere in the farm settings following manure application (Pornsukarom et al., 2017). The authors concluded that Salmonella antibiotic-resilient determinants of 95-kb conjugable plasmids showed a distinct transferability amid Salmonella serotypes in North Carolina, highlighting the evidence that manure deposition was capable of enriching the environmental resistome.

Several animal manure samples from central Spain revealed specific ARGs such as aadA, tetA, tetB, str, sull, and sul2.
Additionally, the genes from chicken manure included genes with clinical relevance, including $b l a_{C T X}-M, b l a_{T E M}, m e c A, v a n A$, and $q n r B$ (Esperón et al., 2018). Meanwhile, the pig slurry samples showed highly expressed tet $C$ and tet $M$ levels, along with the mecA gene. In conclusion, detecting a set comprising 11 ARGs from 18 in amended soil was suggested to support the hypothesis that such a wide magnitude of genes could represent an anthropogenic impact indicator of the environment.

A recent study showed a great prevalence of multi-drug resistant Enterobacteriaceae, including their high resistance gene set, observed in the livestock manure that belonged to different farms and slaughterhouses in Portugal (Amador et al., 2019). The authors identified that the most ARGs persistent isolates (79\%) were obtained from pig manure that also displayed a resistance rate between 0.6 and $80.8 \%$, and the main ARGs genes were attributed to chloramphenicol (catI and catII), ciprofloxacin ( $q n r S, q n r B$, and $o q x)$, tetracycline (tet $A$ and tet $M$ ) and trimethoprim/sulfamethoxazole (dfrIa and sul3), respectively. A similar Enterococcal antibiotic-resistant trait was recently mentioned by other researchers that identified a total of 835 enterococci from soil and chicken litter with the most prevalent species of E. casseliflavus and with the least infrequent being E. gallinarum (Fatoba et al., 2021). Their results described that approximately half of the isolates showed strong resistance to at least one of the evaluated antibiotics with the highest resilience against tetracycline (33\%) at the same time, all of the isolates were susceptible to gentamicin linezolid and tigecycline.

\section{CONCLUSION}

A complex relationship exists between soil health and agricultural practices. Agriculturally induced soil property alterations have the potential to influence the soil microbiome, directly and indirectly, and subsequently impact on soil health. Application of manure to agricultural land can influence physical, chemical and biological soil properties. Microbiological contents of manure have the potential to spread zoonotic pathogens and ARG's to the wider environment, where altered pathogen levels in any instance may have a detrimental impact on human and livestock populations. Understanding the relationship between manure management, microbial content, land application, soil and manure microbiome interaction and pathogen survival is key in finding the sensitive and important balance between effective and sustainable agricultural production.

\section{AUTHOR CONTRIBUTIONS}

ZB, IB, LB, PN, JD, and NC wrote the manuscript. All authors read and approved the final manuscript.

\section{FUNDING}

This work was funded by the Department of Agriculture, Environment and Rural Affairs (DAERA); https://www.daerani.gov.uk) as part of the DAERA Postgraduate Studentship 
Programme and by the DAERA Evidence and Innovation project 18/1/21: Evaluating the impact of a range of organic manures applied to arable land on soil, crop and NI agriculture.

\section{REFERENCES}

Aarons, S. R., O'Connor, C. R., Hosseini, H. M., and Gourley, C. J. (2009). Dung pads increase pasture production, soil nutrients and microbial biomass carbon in grazed dairy systems. Nutr. Cycl. Agroecosyst. 84, 81-92. doi: 10.1007/ s10705-008-9228-5

Adegoke, A. A., Awolusi, O. O., and Stenström, T. A. (2016). Organic Fertilizers: Public Health Intricacies. Organic Fertilizers-From Basic Concepts to Applied Outcomes. Rijeka: Intech, 343-374.

Agga, G. E., Kasumba, J., Loughrin, J. H., and Conte, E. D. (2020). Anaerobic digestion of tetracycline spiked livestock manure and poultry litter increased the abundances of antibiotic and heavy metal resistance genes. Front. Microbiol. 11:614424. doi: $10.3389 /$ fmicb.2020.614424

Albihn, A., and Vinnerås, B. (2007). Biosecurity and arable use of manure and biowaste-Treatment alternatives. Livest. Sci. 112, 232-239. doi: 10.1016/j. livsci.2007.09.015

Alegbeleye, O. O., and Sant'Ana, A. S. (2020). Manure-borne pathogens as an important source of water contamination: an update on the dynamics of pathogen survival/transport as well as practical risk mitigation strategies. Int. J. Hygiene Environ. Health 227:113524. doi: 10.1016/j.ijheh.2020.113524

Amador, P., Fernandes, R., Prudêncio, C., and Duarte, I. (2019). Prevalence of antibiotic resistance genes in multidrug-resistant Enterobacteriaceae on portuguese livestock manure. Antibiotics 8:23. doi: 10.3390/antibiotics8010023

An, J.-U., Ho, H., Kim, J., Kim, W.-H., Kim, J., Lee, S., et al. (2018). Dairy cattle, a potential reservoir of human campylobacteriosis: epidemiological and molecular characterization of Campylobacter jejuni from cattle farms. Front. Microbiol. 9:3136. doi: 10.3389/fmicb.2018.03136

Anwar, M., Patra, D., Chand, S., Alpesh, K., Naqvi, A. A., and Khanuja, S. (2005). Effect of organic manures and inorganic fertilizer on growth, herb and oil yield, nutrient accumulation, and oil quality of French basil. Commun. Soil Sci. Plant Anal. 36, 1737-1746. doi: 10.1081/css-200062434

Atidégla, S. C., Huat, J., Agbossou, E. K., Saint-Macary, H., and Glèlè Kakai, R. (2016). Vegetable contamination by the fecal bacteria of poultry manure: case study of gardening sites in Southern Benin. Int. J. Food Sci. 2016:4767453. doi: 10.1155/2016/4767453

Attwood, G. T., Wakelin, S. A., Leahy, S. C., Rowe, S., Clarke, S., Chapman, D. F., et al. (2019). Applications of the soil, plant and rumen microbiomes in pastoral agriculture. Front. Nutr. 6:107. doi: 10.3389/fnut.2019.00107

Barbour, E. K., Husseini, S. A., Farran, M. T., Itani, D. A., Houalla, R. H., and Hamadeh, S. K. (2002). Soil solarization: a sustainable agriculture approach to reduce microorganisms in chicken manure-treated soil. J. Sustain. Agric. 19, 95-104. doi: 10.1300/j064v19n04_09

Beattie, R. E., Bakke, E., Konopek, N., Thill, R., Munson, E., and Hristova, K. R. (2020). Antimicrobial resistance traits of Escherichia coli isolated from dairy manure and freshwater ecosystems are similar to one another but differ from associated clinical isolates. Microorganisms 8:747. doi: 10.3390/ microorganisms 8050747

Bicudo, J. R., and Goyal, S. M. (2003). Pathogens and manure management systems: a review. Environ. Technol. 24, 115-130. doi: 10.1080/09593330309385542

Blaiotta, G., Di Cerbo, A., Murru, N., Coppola, R., and Aponte, M. (2016). Persistence of bacterial indicators and zoonotic pathogens in contaminated cattle wastes. BMC Microbiol. 16:87.

Blaser, M. J., and Newman, L. S. (1982). A review of human salmonellosis: I. Infective dose. Rev. Infect. Dis. 4, 1096-1106. doi: 10.1093/clinids/4.6.1096

Boateng, S. A., Zickermann, J., and Kornahrens, M. (2006). Poultry manure effect on growth and yield of maize. West Afr. J. Appl. Ecol. 9, 12-18.

Bore, E. K., Apostel, C., Halicki, S., Kuzyakov, Y., and Dippold, M. A. (2017). Soil microorganisms can overcome respiration inhibition by coupling intra-and extracellular metabolism: $13 \mathrm{C}$ metabolic tracing reveals the mechanisms. ISME J. 11, 1423-1433. doi: 10.1038/ismej.2017.3

Bradford, S. A., Morales, V. L., Zhang, W., Harvey, R. W., Packman, A. I., Mohanram, A., et al. (2013). Transport and fate of microbial pathogens in

\section{ACKNOWLEDGMENTS}

\author{
We wish to thank DAERA, the project funders.
}

agricultural settings. Crit. Rev. Environ. Sci. Technol. 43, 775-893. doi: 10.1080/ 10643389.2012.710449

Brandl, M. T., Haxo, A. F., Bates, A. H., and Mandrell, R. E. (2004). Comparison of survival of Campylobacter jejuni in the phyllosphere with that in the rhizosphere of spinach and radish plants. Appl. Environ. Microbiol. 70, 11821189. doi: 10.1128/AEM.70.2.1182-1189.2004

Bronowski, C., James, C. E., and Winstanley, C. (2014). Role of environmental survival in transmission of Campylobacter jejuni. FEMS Microbiol. Lett. 356, 8-19. doi: 10.1111/1574-6968.12488

Brunhede, M. Z., Santos, P. T. D., Gal, L., Garmyn, D., Kallipolitis, B. H., and Piveteau, P. (2020). LisRK is required for optimal fitness of Listeria monocytogenes in soil. FEMS Microbiol. Lett. 367:fnaa188. doi: 10.1093/femsle/ fnaa188

Bui, X. T., Wolff, A., Madsen, M., and Duong Bang, D. (2011). Fate and survival of Campylobacter coli in swine manure at various temperatures. Front. Microbiol. 2:262. doi: 10.3389/fmicb.2011.00262

Bünemann, E., Schwenke, G., and Van Zwieten, L. (2006). Impact of agricultural inputs on soil organisms - A review. Austr. J. Soil Res. 44, 379-406. doi: $10.1071 /$ sr05125

Capellini, F. M., Vencia, W., Amadori, M., Mignone, G., Parisi, E., Masiello, L., et al. (2020). Characterization of MDCK cells and evaluation of their ability to respond to infectious and non-infectious stressors. Cytotechnology 72, 97-109. doi: 10.1007/s10616-019-00360-z

Chaudhari, S., Upadhyay, A., and Kulshreshtha, S. (2021). "Influence of organic amendments on soil properties, microflora and plant growth," in Sustainable Agriculture Reviews, Vol. 52, ed. E. Lichtfouse (Cham: Springer International Publishing), 147-191. doi: 10.1007/s00248-009-9489-9

Checcucci, A., Trevisi, P., Luise, D., Modesto, M., Blasioli, S., Braschi, I., et al. (2020). Exploring the animal waste resistome: the spread of antimicrobial resistance genes through the use of livestock manure. Front. Microbiol. 11:1416. doi: $10.3389 /$ fmicb.2020.01416

Chekabab, S. M., Paquin-Veillette, J., Dozois, C. M., and Harel, J. (2013). The ecological habitat and transmission of Escherichia coli O157: H7. FEMS microbiology letters 341, 1-12. doi: 10.1111/1574-6968.12078

Chlebicz, A., and Śliżewska, K. (2018). Campylobacteriosis, salmonellosis, yersiniosis, and listeriosis as zoonotic foodborne diseases: a review. Int. J. Environ. Res. Public Health 15:863. doi: 10.3390/ijerph15050863

Chuppava, B., Keller, B., Abd El-Wahab, A., Sürie, C., and Visscher, C. (2019). Resistance reservoirs and multi-drug resistance of commensal Escherichia coli from excreta and manure isolated in broiler houses with different flooring designs. Front. Microbiol. 10:2633. doi: $10.3389 /$ fmicb. 2019.02633

Colles, F. M., Jones, T. A., McCarthy, N. D., Sheppard, S. K., Cody, A. J., Dingle, K. E., et al. (2008). Campylobacter infection of broiler chickens in a free-range environment. Environ. Microbiol. 10, 2042-2050.

Congilosi, J. L., and Aga, D. S. (2021). Review on the fate of antimicrobials, antimicrobial resistance genes, and other micropollutants in manure during enhanced anaerobic digestion and composting. J. Hazard. Mater. 405:123634. doi: 10.1016/j.jhazmat.2020.123634

Costa, D., and Iraola, G. (2019). Pathogenomics of emerging Campylobacter Species. Clin. Microbiol. Rev. 32, e00072-18.

Dar, M. A., Ahmad, S. M., Bhat, S. A., Ahmed, R., Urwat, U., Mumtaz, P. T., et al. (2017). Salmonella typhimurium in poultry: a review. Worlds Poultry Sci. J. 73, 345-354.

Delmas, J., Dalmasso, G., and Bonnet, R. (2015). Escherichia coli: the good, the bad and the ugly. Clin. Microbiol. 4:2.

dikovic-Kolic, N. U., Wichmann, F., Broderick, N. A., and Handelsman, J. (2014). Bloom of resident antibiotic-resistant bacteria in soil following manure fertilization. Proc. Natl. Acad. Sci. U.S.A. 111:15202. doi: 10.1073/pnas. 1409836111

EARA (2020). Department of Agriculture, Nutrients Action Programme (NAP) 2019-2022. London: EARA. 
Ekman, J., Goldwater, A., Bradbury, M., Matthews, J., and Rogers, G. (2021). Persistence of human pathogens in manure-amended Australian soils used for production of leafy vegetables. Agriculture 11:14.

El Khatib, M., Tran, Q.-T., Nasrallah, C., Lopes, J., Bolla, J.-M., Vivaudou, M., et al. (2017). Providencia stuartii form biofilms and floating communities of cells that display high resistance to environmental insults. PLoS One 12:e174213. doi: 10.1371 /journal.pone.0174213

England, L. S., Lee, H., and Trevors, J. T. (1993). Bacterial survival in soil: effect of clays and protozoa. Soil Biol. Biochem. 25, 525-531. doi: 10.1016/0038-0717(93) 90189-i

Epps, S. V., Harvey, R. B., Hume, M. E., Phillips, T. D., Anderson, R. C., and Nisbet, D. J. (2013). Foodborne Campylobacter: infections, metabolism, pathogenesis and reservoirs. Int. J. Environ. Res. Public Health 10, 6292-6304. doi: 10.3390/ ijerph 10126292

Esperón, F., Albero, B., Ugarte-Ruíz, M., Domínguez, L., Carballo, M., Tadeo, J. L., et al. (2020). Assessing the benefits of composting poultry manure in reducing antimicrobial residues, pathogenic bacteria, and antimicrobial resistance genes: a field-scale study. Environ. Sci. Pollut. Res. 27, 27738-27749. doi: 10.1007/ s11356-020-09097-1

Esperón, F., Sacristan, C., Carballo, M., and De la Torrre, A. (2018). Antimicrobial resistance genes in animal manure, manure-amended and nonanthropogenically impacted soils in Spain. Adv. Biosci. Biotechnol. 09, 469-480. doi: 10.4236/abb.2018.99032

Falardeau, J., Walji, K., Haure, M., Fong, K., Taylor, G., Ma, Y., et al. (2018). Native bacterial communities and Listeria monocytogenes survival in soils collected from the Lower Mainland of British Columbia, Canada. Can. J. Microbiol. 64, 695-705. doi: 10.1139/cjm-2018-0115

Fatoba, D. O., Abia, A. L. K., Amoako, D. G., and Essack, S. Y. (2021). Rethinking manure application: increase in multidrug-resistant enterococcus spp. in agricultural soil following chicken litter application. Microorganisms 9:885. doi: 10.3390/microorganisms 9050885

Fenlon, D., Ogden, I., Vinten, A., and Svoboda, I. (2000). The fate of Escherichia coli and E. coli O157 in cattle slurry after application to land. J. Appl. Microbiol. 88,149 S-156S.

Fremaux, B., Prigent-Combaret, C., and Vernozy-Rozand, C. (2008). Long-term survival of Shiga toxin-producing Escherichia coli in cattle effluents and environment: an updated review. Vet. Microbiol. 132, 1-18. doi: 10.1016/j. vetmic.2008.05.015

Garcia, R., Baelum, J., Fredslund, L., Santorum, P., and Jacobsen, C. (2010). Influence of temperature and predation on survival of Salmonella enterica serovar Typhimurium and expression of invA in soil and manure-amended soil. Appl. Environ. Microbiol. 76, 5025-5031. doi: 10.1128/AEM.00628-10

García-Sánchez, L., Melero, B., and Rovira, J. (2018). Campylobacter in the food chain. Adv. Food Nutr. Res. 86, 215-252.

Ge, C., Lee, C., and Lee, J. (2012). The impact of extreme weather events on Salmonella internalization in lettuce and green onion. Food Res. Int. 45, 11181122 .

Glenn, L. M., Lindsey, R. L., Frank, J. F., Meinersmann, R. J., Englen, M. D., Fedorka-Cray, P. J., et al. (2011). Analysis of antimicrobial resistance genes detected in multidrug-resistant Salmonella enterica serovar Typhimurium isolated from food animals. Microb. Drug Resist. (Larchmont, N.Y.) 17, 407-418. doi: 10.1089/mdr.2010.0189

Guan, T. T., and Holley, R. A. (2003). Pathogen survival in swine manure environments and transmission of human enteric illness-a review. J. Environ. Qual. 32, 383-392. doi: 10.2134/jeq2003.3830

Gundogdu, O., and Wren, B. W. (2020). Microbe Profile: Campylobacter jejunisurvival instincts. Microbiology 166, 230-232. doi: 10.1099/mic.0.000906

Guo, X., Chen, J., Brackett, R. E., and Beuchat, L. R. (2002). Survival of Salmonella on tomatoes stored at high relative humidity, in soil, and on tomatoes in contact with soil. J. Food Prot. 65, 274-279. doi: 10.4315/0362-028x-65.2.274

Gurmessa, B., Ashworth, A. J., Yang, Y., Savin, M., Moore, P. A., Ricke, S. C., et al. (2021). Variations in bacterial community structure and antimicrobial resistance gene abundance in cattle manure and poultry litter. Environ. Res. 197:111011. doi: 10.1016/j.envres.2021.111011

Hara-Kudo, Y., and Takatori, K. (2011). Contamination level and ingestion dose of foodborne pathogens associated with infections. Epidemiol. Infect. 139, 1505-1510. doi: $10.1017 /$ s095026881000292x
Harvey, R. B., Anderson, R. C., Young, C. R., Hume, M. E., Genovese, K. J., Ziprin, R. L., et al. (1999). Prevalence of Campylobacter, Salmonella, and Arcobacter species at Slaughter in Market age Pigs, Mechanisms in the Pathogenesis of Enteric Diseases, Vol. 2. Cham: Springer, 237-239.

Holman, D. B., Hao, X., Topp, E., Yang, H. E., and Alexander, T. W. (2016). Effect of co-composting cattle manure with construction and demolition waste on the archaeal, bacterial, and fungal microbiota, and on antimicrobial resistance determinants. PLoS One 11:e0157539. doi: 10.1371/journal.pone.0157539

Hutchison, M. L., Walters, L. D., Moore, T., Thomas, D. J. I., and Avery, S. M. (2005). Fate of pathogens present in livestock wastes spread onto fescue plots. Appl. Environ. Microbiol. 71, 691-696. doi: 10.1128/AEM.71.2.691-696.2005

Hutchison, M., Walters, L., Avery, S., Synge, B., and Moore, A. (2004). Levels of zoonotic agents in British livestock manures. Lett. Appl. Microbiol. 39, 207-214. doi: 10.1111/j.1472-765X.2004.01564.x

Indikova, I., Humphrey, T. J., and Hilbert, F. (2015). Survival with a helping hand: Campylobacter and microbiota. Front. Microbiol. 6:1266.

Iwu, C. D., and Okoh, A. I. (2020). Characterization of antibiogram fingerprints in Listeria monocytogenes recovered from irrigation water and agricultural soil samples. PLoS One 15:e0228956. doi: 10.1371/journal.pone.0228956

Iwu, C. D., du Plessis, E., Korsten, L., and Okoh, A. I. (2021). Prevalence of E. coli O157:H7 strains in irrigation water and agricultural soil in two district municipalities in South Africa. Int. J. Environ. Stud. 78, 474-483. doi: 10.1080/ 00207233.2020 .1834318

Jacobsen, C. S., and Bech, T. B. (2012). Soil survival of Salmonella and transfer to freshwater and fresh produce. Food Res. Int. 45, 557-566.

Jiang, X., Morgan, J., and Doyle, M. P. (2002). Fate of Escherichia coli O157: H7 in manure-amended soil. Appl. Environ. Microbiol. 68, 2605-2609. doi: 10.1128/aem.68.5.2605-2609.2002

Jokinen, C. C., Edge, T. A., Koning, W., Laing, C. R., Lapen, D. R., Miller, J., et al. (2012). Spatial and temporal drivers of zoonotic pathogen contamination of an agricultural watershed. J. Environ. Qual. 41, 242-252. doi: 10.2134/jeq2011. 0203

Jung, Y., Jang, H., and Matthews, K. R. (2014). Effect of the food production chain from farm practices to vegetable processing on outbreak incidence. Microb. Biotechnol. 7, 517-527. doi: 10.1111/1751-7915.12178

Kaper, J. B., Nataro, J. P., and Mobley, H. L. (2004). Pathogenic Escherichia coli. Nat. Rev. Microbiol. 2, 123-140. doi: 10.1109/TCBB.2021.3074567

Kibblewhite, M., Ritz, K., and Swift, M. (2008). Soil health in agricultural systems. Philos. Trans. R. Soc. B Biol. Sci. 363, 685-701.

Kirk, J. H. (1998). Pathogens in Manure, School of Veterinary Medicine. Davis Tuke, CA: University of California.

Kothary, M. H., and Babu, U. S. (2001). Infective dose of foodborne pathogens in volunteers: a review. J. Food Saf. 21, 49-68.

Kudva, I. T., Blanch, K., and Hovde, C. J. (1998). Analysis of Escherichia coli O157: H7 survival in ovine or bovine manure and manure slurry. Appl. Environ. Microbiol. 64, 3166-3174. doi: 10.1128/aem.64.9.3166-3174.1998

Kumar, D., Pornsukarom, S., Sivaraman, G. K., and Thakur, S. (2017). Environmental dissemination of multidrug methicillin-resistant Staphylococcus sciuri after application of manure from commercial swine production systems. Foodborne Pathog. Dis. 15, 210-217. doi: 10.1089/fpd.2017.2354

Kurmasheva, N., Vorobiev, V., Sharipova, M., Efremova, T., and Mardanova, A. (2018). The potential virulence factors of Providencia stuartii: motility, adherence, and invasion. BioMed Res. Int. 2018:3589135. doi: 10.1155/2018/ 3589135

Laconi, A., Mughini-Gras, L., Tolosi, R., Grilli, G., Trocino, A., Carraro, L., et al. (2021). Microbial community composition and antimicrobial resistance in agricultural soils fertilized with livestock manure from conventional farming in Northern Italy. Sci. Total Environ. 760, 143404. doi: 10.1016/j.scitotenv.2020. 143404

Larney, F. J., Li, L., Janzen, H. H., Angers, D. A., and Olson, B. M. (2016). Soil quality attributes, soil resilience, and legacy effects following topsoil removal and one-time amendments. Can. J. Soil Sci. 96, 177-190. doi: 10.1139/cjss2015-0089

Larramendy, M., and Soloneski, S. (2016). Organic Fertilizers; From Basic Concepts to Applied Outcomes. BoD-Books on Demand. London: Intechopen.

Layton, D. S., Choudhary, A., and Bean, A. G. (2017). Breaking the chain of zoonoses through biosecurity in livestock. Vaccine 35, 5967-5973. doi: 10.1016/ j.vaccine.2017.07.110 
Li, J., Feng, J., Ma, L., de la Fuente Núñez, C., Gölz, G., and Lu, X. (2017). Effects of meat juice on biofilm formation of Campylobacter and Salmonella. Int. J. Food Microbiol. 253, 20-28.

Liao, J., Guo, X., Weller, D. L., Pollak, S., Buckley, D. H., Wiedmann, M., et al. (2021). Nationwide genomic atlas of soil-dwelling Listeria reveals effects of selection and population ecology on pangenome evolution. Nat. Microbiol. 6, 1021-1030. doi: 10.1038/s41564-021-00935-7

Lim, J. Y., Yoon, J. W., and Hovde, C. J. (2010). A brief overview of Escherichia coli O157: H7 and its plasmid O157. J. Microbiol. Biotechnol. 20:5. doi: 10.4014/ jmb.0908.08007

Lima, T., Domingues, S., and Da Silva, G. J. (2020). Manure as a potential hotspot for antibiotic resistance dissemination by horizontal gene transfer events. Vet. Sci. 7:110. doi: 10.3390/vetsci7030110

Locatelli, A., Spor, A., Jolivet, C., Piveteau, P., and Hartmann, A. (2013). biotic and abiotic soil properties influence survival of Listeria monocytogenes in soil. PLoS One 8:e75969. doi: 10.1371/journal.pone.0075969

Longhurst, P. J., Tompkins, D., Pollard, S. J. T., Hough, R. L., Chambers, B., Gale, P., et al. (2019). Risk assessments for quality-assured, source-segregated composts and anaerobic digestates for a circular bioeconomy in the UK. Environ. Int. 127, 253-266. doi: 10.1016/j.envint.2019.03.044

Lopatto, E., Choi, J., Colina, A., Ma, L., Howe, A., and Hinsa-Leasure, S. (2019). Characterizing the soil microbiome and quantifying antibiotic resistance gene dynamics in agricultural soil following swine CAFO manure application. PLoS One 14:e0220770. doi: 10.1371/journal.pone.0220770

Loss, A., da Rosa Couto, R., Brunetto, G., da Veiga, M., Toselli, M., and Baldi, E. (2019). Animal manure as fertilizer: changes in soil attributes, productivity and food composition. Int. J. Res. Granthaalayah 7, 307-331. doi: 10.29121/ granthaalayah.v7.i9.2019.615

Manyi-Loh, C. E., Mamphweli, S. N., Meyer, E. L., Makaka, G., Simon, M., and Okoh, A. I. (2016). An overview of the control of bacterial pathogens in cattle manure. Int. J. Environ. Res. Public Health 13:843. doi: 10.3390/ijerph13090843

Marinho, C. M., Garmyn, D., Gal, L., Brunhede, M. Z., O’Byrne, C., and Piveteau, P. (2020). Investigation of the roles of AgrA and $\sigma \mathrm{B}$ regulators in Listeria monocytogenes adaptation to roots and soil. FEMS Microbiol. Lett. 367:fnaa036.

Massé, J., Lardé, H., Fairbrother, J. M., Roy, J.-P., Francoz, D., Dufour, S., et al. (2021). Prevalence of antimicrobial resistance and characteristics of Escherichia coli isolates from fecal and manure pit samples on dairy farms in the province of Québec, Canada. Front. Vet. Sci. 8:654125. doi: 10.3389/fvets.2021.654125

Maule, A. (1997). "Survival of the verotoxigenic strain E. coli O157:H7 in laboratory-scale microcosms," in Coliforms and Escherichia coli-Problems or Solutions?, eds D. Kay and C. Fricker (London: Royal Society of Chemistry), 61-65.

Mazur, Z., and Mazur, T. (2015). Effects of long-term organic and mineral fertilizer applications on soil nitrogen content. Polish J. Environ. Stud. 24, 2073-2078. doi: $10.15244 /$ pjoes $/ 42297$

McLaughlin, M. J., McBeath, T. M., Smernik, R., Stacey, S. P., Ajiboye, B., and Guppy, C. (2011). The chemical nature of $P$ accumulation in agricultural soilsimplications for fertiliser management and design: an Australian perspective. Plant Soil 349, 69-87.

Mikha, M. M., and Rice, C. W. (2004). Tillage and manure effects on soil and aggregate-associated carbon and nitrogen. Soil Sci. Soc. Am. J. 68, 809-816. doi: $10.2136 /$ sssaj2004.8090

Miller, D. N., Jurgens, M. E., Durso, L. M., and Schmidt, A. M. (2020). Simulated winter incubation of soil with swine manure differentially affects multiple antimicrobial resistance elements. Front. Microbiol. 11:611912. doi: 10.3389/ fmicb.2020.611912

Monack, D. M. (2012). Salmonella persistence and transmission strategies. Curr. Opin. Microbiol. 15, 100-107. doi: 10.1016/j.mib.2011.10.013

Morita, Y., Kabeya, H., Ishioka, T., Sakawaki, H., Nagai, A., Suzuki, N., et al. (2004). Prevalence of Arcobacter, Campylobacter, and Salmonella spp. in fecal samples from livestock and in retail ground meat. J. Jpn Vet. Med. Assoc. (Japan) 57, 393-397.

Moynihan, E. L., Richards, K. G., Brennan, F. P., Tyrrel, S. F., and Ritz, K. (2015). Enteropathogen survival in soil from different land-uses is predominantly regulated by microbial community composition. Appl. Soil Ecol. 89, 76-84.

Mügler, C., Ribolzi, O., Viguier, M., Janeau, J.-L., Jardé, E., Latsachack, K., et al. (2021). Experimental and modelling evidence of splash effects on manure borne
Escherichia coli washoff. Environ. Sci. Pollut. Res. doi: 10.1007/s11356-02113011-8 [Epub ahead of print].

Murphy, C., Carroll, C., and Jordan, K. (2006). Environmental survival mechanisms of the foodborne pathogen Campylobacter jejuni. J. Appl. Microbiol. 100, 623-632. doi: 10.1111/j.1365-2672.2006.02903.x

Muurinen, J., Stedtfeld, R., Karkman, A., Pärnänen, K., Tiedje, J., and Virta, M. (2017). Influence of manure application on the environmental resistome under finnish agricultural practice with restricted antibiotic use. Environ. Sci. Technol. 51, 5989-5999. doi: 10.1021/acs.est.7b00551

Ngogang, M. P., Ernest, T., Kariuki, J., Mouliom Mouiche, M. M., Ngogang, J., Wade, A., et al. (2021). Microbial contamination of chicken litter manure and antimicrobial resistance threat in an urban area setting in cameroon. Antibiotics 10:20. doi: 10.3390/antibiotics10010020

Nicholson, F. A., Groves, S. J., and Chambers, B. J. (2005). Pathogen survival during livestock manure storage and following land application. Bioresour. Technol. 96, 135-143. doi: 10.1016/j.biortech.2004.02.030

Noyes, N. R., Yang, X., Linke, L. M., Magnuson, R. J., Cook, S. R., Zaheer, R., et al. (2016). Characterization of the resistome in manure, soil and wastewater from dairy and beef production systems. Sci. Rep. 6:24645. doi: 10.1038/srep24645

O'Hara, C. M., Brenner, F. W., and Miller, J. M. (2000). Classification, identification, and clinical significance of Proteus, Providencia, and Morganella. Clin. Microbiol. Rev. 13, 534-546. doi: 10.1128/CMR.13.4.534

Olson, M. E. (2001). "Human and animal pathogens in manure," in Proceedings of the Livestock Options for the Future National Conference, Winnipeg, Manitoba, Canada, June 25-27, 2001, (Ottawa, ON: Agriculture and Agri-Food Canada).

Oporto, B., Esteban, J., Aduriz, G., Juste, R., and Hurtado, A. (2008). Escherichia coli O157: H7 and non-O157 Shiga toxin-producing E. coli in healthy cattle, sheep and swine herds in northern Spain. Zoonoses Public Health 55, 73-81. doi: 10.1111/j.1863-2378.2007.01080.x

Pell, A. N. (1997). Manure and microbes: public and animal health problem? J. Dairy Sci. 80, 2673-2681. doi: 10.3168/jds.s0022-0302(97)76227-1

Pennington, H. (2010). Escherichia coli O157. Lancet 376, 1428-1435.

Plourde, J. D., Pijanowski, B. C., and Pekin, B. K. (2013). Evidence for increased monoculture cropping in the Central United States. Agric. Ecosyst. Environ. 165 50-59. doi: 10.1890/15-0033

Pornsukarom, S., and Thakur, S. (2016). Assessing the impact of manure application in commercial swine farms on the transmission of antimicrobial resistant Salmonella in the environment. PLoS One 11:e0164621. doi: 10.1371/ journal.pone.0164621

Pornsukarom, S., Thakur, S., and Schaffner, D. W. (2017). Horizontal dissemination of antimicrobial resistance determinants in Multiple Salmonella serotypes following isolation from the commercial swine operation environment after manure application. Appl. Environ. Microbiol. 83, e1503-e1517. doi: 10.1128/AEM.01503-17

Pratt, P. (1979). Management restrictions in soil application of manure. J. Anim. Sci. 48, 134-143. doi: 10.2527/jas1979.481134x

Ratzke, C., and Gore, J. (2018). Modifying and reacting to the environmental pH can drive bacterial interactions. PLoS Biol. 16:e2004248. doi: 10.1371/journal. pbio. 2004248

Resende, J. A., Silva, V. L., de Oliveira, T. L., de Oliveira Fortunato, S., da Costa Carneiro, J., Otenio, M. H., et al. (2014). Prevalence and persistence of potentially pathogenic and antibiotic resistant bacteria during anaerobic digestion treatment of cattle manure. Bioresour. Technol. 153, 284-291.

Risse, L., Cabrera, M. L., Franzluebbers, A. J., Gaskin, J. W., Gilley, J. E., Killorn, R., et al. (2006). Land Application of Manure For Beneficial Reuse. St. Joseph, MI: ASABE.

Rukambile, E., Sintchenko, V., Muscatello, G., Kock, R., and Alders, R. (2019). Infection, colonization and shedding of Campylobacter and Salmonella in animals and their contribution to human disease: a review. Zoonoses Public Health 66, 562-578. doi: 10.1111/zph.12611

Ruuskanen, M., Muurinen, J., Meierjohan, A., Pärnänen, K., Tamminen, M., Lyra, C., et al. (2016). Fertilizing with animal manure disseminates antibiotic resistance genes to the farm environment. J. Environ. Qual. 45, 488-493.

Salaheen, S., and Biswas, D. (2019). Organic Farming Practices: Integrated Culture Versus Monoculture, Safety and Practice for Organic Food. Amsterdam: Elsevier, 23-32.

Schmid-Hempel, P., and Frank, S. A. (2007). Pathogenesis, virulence, and infective dose. PLoS Pathog. 3:e147. doi: 10.1371/journal.ppat.0030147 
Segura, A., Auffret, P., Bibbal, D., Bertoni, M., Durand, A., Jubelin, G., et al. (2018). Factors involved in the persistence of a Shiga toxin-producing Escherichia coli O157: H7 strain in bovine feces and gastro-intestinal content. Front. Microbiol. 9:375. doi: 10.3389/fmicb.2018.00375

Semenov, A. V., Van Overbeek, L., and Van Bruggen, A. H. (2009). Percolation and survival of Escherichia coli O157: H7 and Salmonella enterica serovar Typhimurium in soil amended with contaminated dairy manure or slurry. Appl. Environ. Microbiol. 75, 3206-3215. doi: 10.1128/aem.01791-08

Sharma, M., and Reynnells, R. (2016). Importance of soil amendments: survival of bacterial pathogens in manure and compost used as organic fertilizers. Microbiol. Spectr. 4:36.

Sharpley, A., Jarvie, H. P., Buda, A., May, L., Spears, B., and Kleinman, P. (2013). Phosphorus legacy: overcoming the effects of past management practices to mitigate future water quality impairment. J. Environ. Qual. 42, 1308-1326. doi: 10.2134/jeq2013.03.0098

Sibanda, N., McKenna, A., Richmond, A., Ricke, S. C., Callaway, T., Stratakos, A. C., et al. (2018). A review of the effect of management practices on Campylobacter prevalence in poultry farms. Front. Microbiol. 9:2002. doi: 10. 3389/fmicb.2018.02002

Smith, K., and Williams, A. (2016). Production and management of cattle manure in the UK and implications for land application practice. Soil Use Manag. 32, 73-82. doi: 10.1111/sum.12247

Smith, R., Andres, V., Cheney, T., Martelli, F., Gosling, R., Marier, E., et al. (2018). How do pig farms maintain low Salmonella prevalence: a case-control study. Epidemiol. Infect. 146, 1909-1915. doi: 10.1017/S0950268818002248

Sobur, M. A., Sabuj, A. A. M., Sarker, R., Rahman, A. M. M. T., Kabir, S. M. L., and Rahman, M. T. (2019). Antibiotic-resistant Escherichia coli and Salmonella spp. associated with dairy cattle and farm environment having public health significance. Vet. World 12, 984-993. doi: 10.14202/vetworld.2019.984-993

Spector, M. P., and Kenyon, W. J. (2012). Resistance and survival strategies of Salmonella enterica to environmental stresses. Food Res. Int. 45, 455-481. doi: 10.1016/j.foodres.2011.06.056

Spiehs, M. J., and Goyal, S. M. (2007). Best Management Practices for Pathogen Control in Manure Management Systems. University of Minnesota Extension. Available online at: http://lshs.tamu.edu/docs/lshs/endnotes/bmps\%20for\%20pathogen\%20control\%20in\%20manure\%20managemen t\%20systems-1916131611/bmps\%20for\%20pathogen\%20control\%20in\%20m anure\%20management\%20systems.pdf

Stanley, K., and Jones, K. (2003). Cattle and sheep farms as reservoirs of Campylobacter. J. Appl. Microbiol. 94(Suppl.), 104S-113S. doi: 10.1046/j.13652672.94.s1.12.x

Struik, P. C., and Kuyper, T. W. (2017). Sustainable intensification in agriculture: the richer shade of green. A review. Agron. Sustain. Dev. 37:39.

Swanenburg, M., Urlings, H. A. P., Snijders, J. M. A., Keuzenkamp, D. A., and van Knapen, F. (2001). Salmonella in slaughter pigs: prevalence, serotypes and critical control points during slaughter in two slaughterhouses. Int. J. Food Microbiol. 70, 243-254. doi: 10.1016/s0168-1605(01)00545-1

Szott, V., and Friese, A. (2021). Emission sources of Campylobacter from agricultural farms, impact on environmental contamination and intervention strategies. Curr. Top. Microbiol. Immunol. 431, 103-125. doi: 10.1007/978-3030-65481-8_5

Tan, W., Wang, J., Bai, W., Qi, J., and Chen, W. (2020). Soil bacterial diversity correlates with precipitation and soil $\mathrm{pH}$ in long-term maize cropping systems. Sci. Rep. 10:6012. doi: 10.1038/s41598-020-62919-7

Tilman, D., Cassman, K. G., Matson, P. A., Naylor, R., and Polasky, S. (2002). Agricultural sustainability and intensive production practices. Nature 418, 671-677. doi: 10.1038/nature01014

Tilman, D., Fargione, J., Wolff, B., D’antonio, C., Dobson, A., Howarth, R., et al. (2001). Forecasting agriculturally driven global environmental change. Science 292, 281-284.

Tomley, F. M., and Shirley, M. W. (2009). Livestock infectious diseases and zoonoses. Philos. Trans. R. Soc. Lond. B Biol. Sci. 364, 2637-2642.

Tran, D. T., Bradbury, M. I., Ogtrop, F. F. V., Bozkurt, H., Jones, B. J., and McCONCHIE, R. (2020). Environmental drivers for persistence of Escherichia coli and salmonella in manure-amended soils: a meta-analysis. J. Food Protect. 83, 1268-1277. doi: 10.4315/0362-028X.JFP-19-460

Tuttle, J., Gomez, T., Doyle, M. P., Wells, J. G., Zhao, T., Tauxe, R. V., et al. (1999). Lessons from a large outbreak of Escherichia coli O157[ratio]H7 infections: insights into the infectious dose and method of widespread contamination of hamburger patties. Epidemiol. Infect. 122, 185-192. doi: $10.1017 / \mathrm{s} 0950268898001976$

van Elsas, J. D., Chiurazzi, M., Mallon, C. A., Elhottovā, D., Krištůfek, V., and Salles, J. F. (2012). Microbial diversity determines the invasion of soil by a bacterial pathogen. Proc. Natl. Acad. Sci. U.S.A. 109, 1159-1164. doi: 10.1073/ pnas.1109326109

van Vliet, P. C. J., Reijs, J. W., Bloem, J., Dijkstra, J., and de Goede, R. G. M. (2007). Effects of cow diet on the microbial community and organic matter and nitrogen content of feces. J. Dairy Sci. 90, 5146-5158. doi: $10.3168 /$ jds.2007-0065

Vernozy-Rozand, C., Montet, M., Lequerrec, F., Serillon, E., Tilly, B., Bavai, C., et al. (2002). Prevalence of verotoxin-producing Escherichia coli (VTEC) in slurry, farmyard manure and sewage sludge in France. J. Appl. Microbiol. 93, 473-478. doi: 10.1046/j.1365-2672.2002.01706.x

Vidovic, S., Block, H. C., and Korber, D. R. (2007). Effect of soil composition, temperature, indigenous microflora, and environmental conditions on the survival of Escherichia coli O157:H7. Can. J. Microbiol. 53, 822-829. doi: 10. 1139/W07-041

Vivant, A.-L., Desneux, J., Pourcher, A.-M., and Piveteau, P. (2017). Transcriptomic analysis of the adaptation of Listeria monocytogenes to lagoon and soil matrices associated with a piggery environment: comparison of expression profiles. Front. Microbiol. 8:1811. doi: 10.3389/fmicb.2017.01811

Wagenaar, J. A., French, N. P., and Havelaar, A. H. (2013). Preventing Campylobacter at the source: why is it so difficult? Clin. Infect. Dis. 57, 16001606. doi: $10.1093 / \mathrm{cid} / \mathrm{cit} 555$

Waggoner, P. E. (1995). How much land can ten billion people spare for nature? Does technology make a difference? Technol. Soc. 17, 17-34. doi: 10.1016/0160$791 \times(94) 00024-8$

Waldner, L. L., MacKenzie, K. D., Köster, W., and White, A. P. (2012). From exit to entry: long-term survival and transmission of Salmonella. Pathogens 1, 128-155. doi: $10.3390 /$ pathogens 1020128

Wallis, M. (1994). The pathogenesis of Campylobacter jejuni. Br. J. Biomed. Sci. 51, 57-64.

Wang, G., Zhao, T., and Doyle, M. P. (1996). Fate of enterohemorrhagic Escherichia coli O157:H7 in bovine feces. Appl. Environ. Microbiol. 62, 2567-2570. doi: 10.1128/aem.62.7.2567-2570.1996

Wang, M., Liu, P., Xiong, W., Zhou, Q., Wangxiao, J., Zeng, Z., et al. (2018). Fate of potential indicator antimicrobial resistance genes (ARGs) and bacterial community diversity in simulated manure-soil microcosms. Ecotoxicol. Environ. Saf. 147, 817-823. doi: 10.1016/j.ecoenv.2017.09.055

Wang, M., Sun, Y., Liu, P., Sun, J., Zhou, Q., Xiong, W., et al. (2017). Fate of antimicrobial resistance genes in response to application of poultry and swine manure in simulated manure-soil microcosms and manure-pond microcosms. Environ. Sci. Pollut. Res. 24, 20949-20958. doi: 10.1007/s11356-0179623-z

Welshimer, H. J. (1960). Survival of Listeria monocytogenes in soil. J. Bacteriol. 80, 316-320. doi: 10.1128/jb.80.3.316-320.1960

Wesley, I. V., Wells, S. J., Harmon, K. M., Green, A., Schroeder-Tucker, L., Glover, M., et al. (2000). Fecal shedding of Campylobacter and Arcobacter spp. in dairy cattle. Appl. Environ. Microbiol. 66, 1994-2000. doi: 10.1128/aem.66.5.19942000.2000

Wie, S.-H. (2015). Clinical significance of Providencia bacteremia or bacteriuria. Korean J. Intern. Med. 30, 167-169. doi: 10.3904/kjim.2015.30.2.167

Wiles, T. J., Kulesus, R. R., and Mulvey, M. A. (2008). Origins and virulence mechanisms of uropathogenic Escherichia coli. Exp. Mol. Pathol. 85, 11-19. doi: 10.1016/j.yexmp.2008.03.007

Williams, A. P., Avery, L. M., Killham, K., and Jones, D. L. (2005). Persistence of Escherichia coli $\mathrm{O} 157$ on farm surfaces under different environmental conditions. J. Appl. Microbiol. 98, 1075-1083. doi: 10.1111/j.1365-2672.2004. 02530.x

Williamson, D. A., Lane, C. R., Easton, M., Valcanis, M., Strachan, J., Veitch, M. G., et al. (2018). Increasing antimicrobial resistance in nontyphoidal Salmonella isolates in Australia from 1979 to 2015. Antimicrob. Agents Chemother. 62, e2012-e2017. doi: 10.1128/AAC.02012-17

Wilson, D. J., Gabriel, E., Leatherbarrow, A. J. H., Cheesbrough, J., Gee, S., Bolton, E., et al. (2008). Tracing the source of Campylobacteriosis. PLoS Genet. 4:e1000203. doi: 10.1371/journal.pgen. 1000203 
Wimalarathna, H. M., Richardson, J. F., Lawson, A. J., Elson, R., Meldrum, R., Little, C. L., et al. (2013). Widespread acquisition of antimicrobial resistance among Campylobacter isolates from UK retail poultry and evidence for clonal expansion of resistant lineages. BMC Microbiol. 13:160. doi: 10.1186/14712180-13-160

Winfield, M. D., and Groisman, E. A. (2003). Role of nonhost environments in the lifestyles of Salmonella and Escherichia coli. Appl. Environ. Microbiol. 69, 3687-3694. doi: 10.1128/AEM.69.7.3687-3694.2003

Wortmann, C. S., and Shapiro, C. A. (2008). The effects of manure application on soil aggregation. Nutr. Cycl. Agroecosyst. 80, 173-180. doi: 10.1007/s10705-007-9130-6

Xing, J., Wang, H., Brookes, P. C., Salles, J. F., and Xu, J. (2019). Soil pH and microbial diversity constrain the survival of E. coli in soil. Soil Biol. Biochem. 128, 139-149. doi: 10.1016/j.soilbio.2018.10.013

Xiong, L., Sun, Y., Shi, L., and Yan, H. (2019). Characterization of antimicrobial resistance genes and class 1 integrase gene in raw meat and aquatic product, fresh vegetable and fruit, and swine manure in southern China. Food Control 104, 240-246. doi: 10.1016/j.foodcont.2019.05.004

Xu, S., Amarakoon, I. D., Zaheer, R., Smith, A., Sura, S., Wang, G., et al. (2018). Dissipation of antimicrobial resistance genes in compost originating from cattle manure after direct oral administration or post-excretion fortification of antimicrobials. J. Environ. Sci. Health A Tox. Hazard. Subst. Environ. Eng. 53, 373-384. doi: 10.1080/10934529.2017.1404337

Xu, S., Schwinghamer, T., Sura, S., Cessna, A. J., Zvomuya, F., Zaheer, R., et al. (2021). Degradation of antimicrobial resistance genes within stockpiled beef cattle feedlot manure. J. Environ. Sci. Health A Tox. Hazard. Subst. Environ. Eng. 56, 1093-1106. doi: 10.1080/10934529.2021.1965416

Xu, S., Sura, S., Zaheer, R., Wang, G., Smith, A., Cook, S., et al. (2016). Dissipation of antimicrobial resistance determinants in composted and stockpiled beef cattle manure. J. Environ. Qual. 45, 528-536. doi: 10.2134/jeq2015.03.0146

Yan, F., and Polk, D. B. (2004). Commensal bacteria in the gut: learning who our friends are. Curr. Opin. Gastroenterol. 20, 565-571. doi: 10.1097/00001574200411000-00011

Yang, T., Siddique, K. H., and Liu, K. (2020). Cropping systems in agriculture and their impact on soil health-a review. Glob. Ecol. Conserv. 23:e01118. doi: 10.1016/j.gecco.2020.e01118

Yao, Z., Yang, L., Wang, H., Wu, J., and Xu, J. (2015). Fate of Escherichia coli O157: $\mathrm{H} 7$ in agricultural soils amended with different organic fertilizers. J. Hazard. Mater. 296, 30-36. doi: 10.1016/j.jhazmat.2015.04.023

Yoshizawa, N., Usui, M., Fukuda, A., Asai, T., Higuchi, H., Okamoto, E., et al. (2020). Manure compost is a potential source of tetracycline-resistant Escherichia coli and Tetracycline resistance genes in Japanese farms. Antibiotics 9:76. doi: 10.3390/antibiotics9020076

Zeng, M., de Vries, W., Bonten, L. T., Zhu, Q., Hao, T., Liu, X., et al. (2017). Modelbased analysis of the long-term effects of fertilization management on cropland soil acidification. Environ. Sci. Technol. 51, 3843-3851. doi: 10.1021/acs.est. 6b05491

Zhang, M.-K., and Fang, L.-P. (2007). Effect of tillage, fertilizer and green manure cropping on soil quality at an abandoned brick making site. Soil Tillage Res. 93, 87-93.

Zhang, Y., Shen, H., He, X., Thomas, B. W., Lupwayi, N. Z., Hao, X., et al. (2017). Fertilization shapes bacterial community structure by alteration of soil pH. Front. Microbiol. 8:1325. doi: 10.3389/fmicb.2017. 01325

Zhang, Y.-J., Hu, H.-W., Chen, Q.-L., Singh, B. K., Yan, H., Chen, D., et al. (2019). Transfer of antibiotic resistance from manureamended soils to vegetable microbiomes. Environ. Int. 130:104912. doi: 10.1016/j.envint.2019.104912

Zhao, Q., Xiong, W., Xing, Y., Sun, Y., Lin, X., and Dong, Y. (2018). Long-term coffee monoculture alters soil chemical properties and microbial communities. Sci. Rep. 8:6116. doi: 10.1038/s41598-018-24537-2

Zhao, Y., Su, J. Q., An, X. L., Huang, F. Y., Rensing, C., Brandt, K. K., et al. (2018). Feed additives shift gut microbiota and enrich antibiotic resistance in swine gut. Sci. Total Environ. 621, 1224-1232.

Zhong, X., Wu, Q., Zhang, J., Ma, Z., Wang, J., Nie, X., et al. (2020). Campylobacter jejuni biofilm formation under aerobic conditions and inhibition by $\mathrm{ZnO}$ nanoparticles. Front. Microbiol. 11:207. doi: 10.3389/fmicb.2020.00207

Zhu, Y.-G., Zhao, Y., Zhu, D., Gillings, M., Penuelas, J., Ok, Y. S., et al. (2019). Soil biota, antimicrobial resistance and planetary health. Environ. Int. 131:105059. doi: 10.1016/j.envint.2019.105059

Conflict of Interest: The authors declare that the research was conducted in the absence of any commercial or financial relationships that could be construed as a potential conflict of interest.

The handling editor declared a past co-authorship with one of the authors NC.

Publisher's Note: All claims expressed in this article are solely those of the authors and do not necessarily represent those of their affiliated organizations, or those of the publisher, the editors and the reviewers. Any product that may be evaluated in this article, or claim that may be made by its manufacturer, is not guaranteed or endorsed by the publisher.

Copyright (c) 2021 Black, Balta, Black, Naughton, Dooley and Corcionivoschi. This is an open-access article distributed under the terms of the Creative Commons Attribution License (CC BY). The use, distribution or reproduction in other forums is permitted, provided the original author(s) and the copyright owner(s) are credited and that the original publication in this journal is cited, in accordance with accepted academic practice. No use, distribution or reproduction is permitted which does not comply with these terms. 